\title{
Biological Control of Chili Damping-Off Disease, Caused by Pythium myriotylum
}

Sajjad Hyder ${ }^{1 *}$, Amjad Shahzad Gondal ${ }^{*}$, Zarrin Fatima Rizvi', Rashida Atiq ${ }^{2}$, Muhammad Irtaza Sajjad Haider ${ }^{3}$, Nida Fatima ${ }^{3}$ and Muhammad Inam-ul-Haq ${ }^{4}$

${ }^{1}$ Department of Botany, Government College Women University, Sialkot, Pakistan, ${ }^{2}$ Department of Plant Pathology, Bahauddin Zakariya University, Multan, Pakistan, ${ }^{3}$ Department of Soil Science and SWC, PMAS Arid Agriculture University, Rawalpindi, Pakistan, ${ }^{4}$ Department of Plant Pathology, PMAS Arid Agriculture University, Rawalpindi, Pakistan

Pythium myriotylum is a notorious soil-borne oomycete that causes post-emergence damping-off in chili pepper. Of various disease management strategies, utilization of plant growth promoting rhizobacteria (PGPR) in disease suppression and plant growth promotion is an interesting strategy. The present study was performed to isolate and characterize PGPR indigenous to the chili rhizosphere in Pakistan, and to test the potential to suppress the damping-off and plant growth promotion in chili. Out of a

Edited by: Gustavo Henrique Goldman, University of São Paulo, Brazil

Reviewed by: Naeem Khan, University of Florida, United States Jay Prakash Verma, Banaras Hindu University, India Bruno Brito Lisboa, State Secretariat of Agriculture, Livestock and Irrigation, Brazil

${ }^{*}$ Correspondence: Amjad Shahzad Gondal amjadshahzad@live.com Sajjad Hyder sajjad.hyder@gcwus.edu.pk

Specialty section: This article was submitted to Fungi and Their Interactions, a section of the journal Frontiers in Microbiology

Received: 26 July 2020 Accepted: 12 April 2021 Published: 13 May 2021

Citation:

Hyder S, Gondal AS, Rizvi ZF, Atiq R, Haider MIS, Fatima $N$ and Inam-ul-Haq M (2021) Biological Control of Chili Damping-Off Disease,

Caused by Pythium myriotylum.

Front. Microbiol. 12:587431. doi: 10.3389/fmicb.2021.587431 total of 28 antagonists, eight bacterial isolates (4a2, JHL-8, JHL-12, 1C2, RH-24, 1D, $5 \mathrm{C}$, and $\mathrm{RH}-87$ ) significantly suppressed the colony growth of $P$. myriotylum in a dual culture experiment. All the tested bacterial isolates were characterized for biochemical attributes, and 16S rRNA sequence based phylogenetic analysis identified these isolates as Flavobacterium spp., Bacillus megaterium, Pseudomonas putida, Bacillus cereus, and Pseudomonas libanensis. All the tested bacterial isolates showed positive test results for ammonia production, starch hydrolase (except 4a2), and hydrogen cyanide production (except 4a2 and 1D). All the tested antagonists produced indole-3-acetic acid (13.4-39.0 $\left.\mu \mathrm{g} \mathrm{mL}^{-1}\right)$, solubilized inorganic phosphate $\left(75-103 \mu \mathrm{g} \mathrm{mL}^{-1}\right)$, and produced siderophores (17.1-23.7\%) in vitro. All the tested bacterial isolates showed varying levels of susceptibility and resistance response against different antibiotics and all these bacterial isolates were found to be non-pathogenic to chili seeds and notably enhanced percentage seed germination, plumule, redical length, and vigor index over un-inoculated control. Additionally, under pathogen pressure, bacterization increased the defense related enzymes such as Peroxidase (PO), polyphenol oxidase (PPO), and phenylalanine ammonia-lyase (PAL) activates. Moreover, the treatment of chill seeds with these bacterial isolates significantly suppressed the damping-off caused by P. myriotylum and improved PGP traits compared to the control. In addition, a positive correlation was noticed between shoot, root length, and dry shoot and root weight, and there was a negative correlation between dry shoot, root weight, and seedling percentage mortality. These results showed that native PGPR possesses multiple traits beneficial to the chili plants and can be used to develop eco-friendly and effective seed treatment formulation as an alternative to synthetic chemical fungicides.

Keywords: antagonism, Bacillus spp., PGPR, Pseudomonas spp., plant growth promotion, Pythium myriotylum, IAA production, siderophore production 


\section{INTRODUCTION}

Chili pepper (Capsicum annuum L.) is a member of Solanaceae family. It is an important vegetable crop worldwide, and is cultivated in Asia on large scale (Tariq et al., 2014). Chili accounts for almost $20 \%$ of the total vegetable growing area in Pakistan. It is consumed as a fresh or processed spice, and serves as a good source of vitamins A and C, phenolics, and carotenoids. Capsaicinoid compound derived from chili has many ethnopharmacological applications including anticancer, anti-obesity treatment, temperature regulation, pain therapy, and antioxidant effects (Meghvansi et al., 2010). Chili crop is vulnerable to more than 100 different types of pathogens during its various growth stages (Jayapala et al., 2019). Of the different microbial diseases that affect this plant, the damping-off and root rot disease caused by Pythium myriotylum Drechsler. is the most devastating disease in terms of seedling mortality at very early growth stages in nurseries, affecting the seedlings when they are in the cotyledonous stage. Pythium spp. are disease causative fungal-like organisms that result in $90 \%$ plant death as pre and/or post-emergence damping-off under favorable conditions. A study has shown that damping-off may affect from 5 to $80 \%$ of the seedlings and result in huge economic losses for farmers (Lamichhane et al., 2017). This disease is characterized by the typical symptoms of rotten roots, necrosis, wilt, water soaking lesions, and the decay of young seedlings (Horst, 2013). P. myriotylum is one of the most commonly occurring species in greenhouses, and in warm and moist soil and present wide host range (Ben-Yephet and Nelson, 1999). Watery soaked, sunken lesions can be seen on the stem at soil level or below the soil on roots, causing the seedling to fall over the ground (Smith, 1975) and excessive soil moisture leads to the development and movement of zoospores which attack the host plants.

Of various other practices, chemical seed coating is widely adopted in agriculture to control the disease (Dorrance et al., 2009; Rothrock et al., 2012; Kandel et al., 2016). Chemicals such as bleach, hydrogen peroxide, ethanol, and fungicides are extensively used to kill the pathogen inoculum present on seed coats (Mancini and Romanazzi, 2014). Chemical seed treatment is an effective practice in controlling the soil and seed borne pathogens but can pose a detrimental effect on seed germination and cause phytotoxicity (du Toit, 2004). Besides this, pesticide residues in soil and water are a potential threat to humans and the environment (Ouyang et al., 2016; Lamichhane et al., 2017), and many of these chemicals have been declared carcinogen pollutants in many countries (Bressa et al., 1997). Non-judicial use of many of these synthetic pesticides and fungicides has come under increasing public scrutiny in different countries (Bourguet and Guillemaud, 2016) and reports on pest resistance development are also increasing the threat for farming (Onstad, 2013). Furthermore, these fungicides are noxious to the survival of beneficial rhizosphere microbes (Hussain et al., 2009). Thus, there is a strong need to find cost effective and environmentally safe alternatives that can minimize or eliminate dependency on synthetic pesticides.

Plant growth promoting rhizobacteria are free-living or plant root colonized bacteria that confer plant growth promotion
(Glick, 2012) and do not cause any harm to their hosts (Ryan et al., 2008). Bacteria belonging to Pseudomonas, Azospirillum, Azotobacter, Klebsiella, Enterobacter, Alcaligenes, Arthobacter, Burkholderia, Bacillus, and Serratia spp. improve plant growth (Kloepper et al., 1989; Souza et al., 2015) are used as biocontrol agents (Liu et al., 2007; Chen et al., 2009; Labuschagne et al., 2010; El-Sayed et al., 2014) and biofertilizers (Vessey, 2003). PGPR promote plant growth by different mechanisms which include the production of Indole acetic acid (IAA) (Etesami et al., 2015), phosphate solubilization (Panhwar et al., 2014), atmospheric nitrogen fixation (Kuan et al., 2016), ACC deaminase activity (Chen et al., 2013) and zinc solubilization (Gupta et al., 2015). PGPR suppress plant pathogens by employing various mechanisms such as competition, siderophores production, antagonism and induced systemic resistance (Gómez-Lama Cabanás et al., 2014), which activate multiple defense-related enzymes to challenge them against a broad spectrum of phytopathogens (Cazorla et al., 2007; Vanitha and Umesha, 2011). Peroxidases (PO) have been involved in many defense-related mechanisms, including the hypersensitive reaction, lignification, cross-linking of phenolics and glycoproteins, and the production of suberization and phytoalexin (Wojtaszek, 1997). Polyphenol oxidase (PPO) catalyzes the oxidation of phenolics to free radicals that react with biological molecules, thus hindering the pathogen development (Jockusch, 1966). Phenylalanine ammonia-lyase (PAL) plays an important role in the regulation of phenylpropanoid production (Achnine et al., 2004) and synthesis of various defenserelated secondary compounds such as phenols and lignin (Tahsili et al., 2014).

Biological control is an alternative strategy to reduce the dependency on agro-chemicals in crop disease management programs (Postma et al., 2003) and the use of PGPR in disease management is helpful to reduce the detrimental effects of agrochemicals on the environment. Many reports are available on the biocontrol potential of PGPR against Pythium spp. and plant growth promotion effect on tomato (Al-Hussini et al., 2019), potato (Kenawy et al., 2019), cucumber (El-Tarabily et al., 2009), sugar beet (Williams and Asher, 1996), cereals (Labuschagne et al., 2010), and many other major crops. In many cases, it has been observed that imported bioformulations sometimes fail to act up to their maximum potential due to climate change (Compant et al., 2010), nutrient availability (Kandeler et al., 2006), and the rhizosphere competence of the microbes (Lugtenberg and Kamilova, 2009). Thus, the identification and characterization of PGPR indigenous to chili rhizospheres is important to screen bacterial isolates that can suppress $P$. myriotylum inoculum and enhance chili growth in nurseries and greenhouses.

Considering the importance of chili production in an ecofriendly environment, this study aimed to isolate and screen native rhizobacteria for their biocontrol potential against the most virulent strain of $P$. myriotylum in vitro, to characterize bacterial agents based on morphological characters, and also by $16 \mathrm{~S}$ rRNA sequence analysis, to examine the effect of bacterial treatment on seed germination, and to study the ability of PGPR to suppress P. myriotylum -induced damping-off and PGP effects 
on chili in pot experiments under growth room conditions. To our knowledge, this is the first report on native PGPR suppressing $P$. myriotylum and enhancing growth promotion in chili from Pakistan.

\section{MATERIALS AND METHODS}

\section{Pathogen Inoculum}

Strains of Pythium myriotylum D. (PMyr-1 and PMyr-2) were previously reported as the causal agent of dampingoff and root rot in chili pepper (Capsicum annum L.) from Punjab, Pakistan (Hyder et al., 2018). Pythium myriotylum was identified on morphological and molecular basis. The ITS1 and ITS2 rDNA sequences of these two virulent strains had been submitted in the GenBank database (accessions no. MF143429 and MF143430), which displayed a 99\% identity with of P. myriotylum (accession no. HQ643704).

\section{Sampling and Isolation of Bacterial Isolates}

Major chili growing fields in Rawalpindi $\left(33.5651^{\circ} \mathrm{N}, 73.0169^{\circ}\right.$ E) Punjab, Pakistan were surveyed and rhizospheric soil samples strictly adhering to chili plant roots were taken from 15 to $20 \mathrm{~cm}$ depth along with the plant roots. All the soil samples were immediately processed for the isolation of rhizobacteria after reaching the laboratory. Bacteria were isolated from $10 \mathrm{~g}$ of soil samples by serial dilution plating on nutrient agar (NA) (HiMedia Laboratories) medium containing Petri plates (Joseph et al., 2012). For the isolation of root colonizing bacteria, $1 \mathrm{~g}$ of the root samples were washed with tap water, surface sterilized using $70 \%$ ethanol for $5 \mathrm{~min}$, followed by $1 \%$ sodium hypochlorite $(\mathrm{NaOCl})$ for $2 \mathrm{~min}$, and then washed five times with sterilized distilled water (Kuan et al., 2016). Sterilized roots were crushed in distilled water aseptically with sterilized mortar and pestle, and were streaked on NA medium followed by incubation at $26 \pm 2{ }^{\circ} \mathrm{C}$ for $24-48 \mathrm{~h}$. Morphologically discrete bacterial colonies were picked aseptically using a sterilized loop and sub-cultured on NA medium containing Petri plates. Bacterial isolates were stored at $-80^{\circ} \mathrm{C}$ in equal volumes of nutrient broth (NB) medium and $30 \%$ glycerol for further use in experiments.

\section{In vitro Screening of Bacterial Isolates Against Pythium myriotylum}

The rhizobacterial isolates $(n=110)$ were tested in repeated experiments for antagonistic potential against two virulent strains of P. myriotylum (PMyr-1 and PMyr-2) by using a dual culture technique (Rabindran and Vidhyasekaran, 1996) on PDA medium containing Petri plates. Small disks of actively growing P. myriotylum $(5 \mathrm{~mm}$ ) were placed in the middle of $9 \mathrm{~cm}$ Petri plates, and counter streaked on two sides by each rhizobacterial isolate about $2.5 \mathrm{~cm}$ from the fungal disks. The control plates contained fungal plugs without bacterial streaks. Petri plates were incubated at $26 \pm 2{ }^{\circ} \mathrm{C}$, and inhibition zones $(\mathrm{cm})$ were measured against each isolate 48 and $96 \mathrm{~h}$ after incubation. Each of the bacterial isolates were tested in five repeats to confirm the results.
The percentage mycelial growth inhibition was recorded using the following formula:

$$
\text { Mycelial growth inhibition }(\%)=\left(\frac{\mathrm{R}-\mathrm{r}}{\mathrm{R}}\right) \times 100
$$

$\mathrm{R}$ is the radius of fungal mycelial growth in the control; $\mathrm{r}$ is the radius of fungal mycelial growth in the treatment.

\section{Biochemical Featuring of Rhizobacterial Isolates}

Bacterial isolates displaying consistent antagonistic responses in repeated dual culture tests were characterized based on Gram type reaction and fluorescence emission using the standard methods as described earlier (Cappuccino and Sherman, 2005). Potassium hydroxide $(\mathrm{KOH})$ solubility tests were performed using the protocol as previously described by Kirsop and Doyle (1991). In this test, a 24-h old bacterial colony grown on NA medium was mixed thoroughly with $3 \% \mathrm{KOH}$ solution on a glass slide and mixed thoroughly. The formation of mucoid thread confirmed the positive results for the bacterial isolates. Catalase tests were performed in accordance with the method described by Hayward (1960). Freshly grown bacterial culture on NA medium was mixed with one drop of $3 \% \mathrm{H}_{2} \mathrm{O}_{2}$ on a glass slide. Rapid gas bubbles formation confirmed the positive test results. Levan production was tested using the procedure described by Lelliott and Stead (1987).

A carbohydrate fermentation test was performed in accordance with the procedure previously described by Aneja (2001). In this test, overnight grown bacterial cultures were inoculated in screw-capped tubes containing sterilized phenol red carbohydrate fermentation broth (1 g Trypticase; $0.5 \mathrm{~g}$ Sodium Chloride; $0.02 \mathrm{mg}$ Phenol red and $0.5 \mathrm{~g}$ carbohydrate in $100 \mathrm{~mL}$ of distilled water). A change in medium color from red to yellow indicated the positive test results.

A hydrogen sulfide $\left(\mathrm{H}_{2} \mathrm{~S}\right)$ production test was performed following the protocol described by Warren et al. (2005). Briefly, the $24 \mathrm{~h}$ old bacterial cultures grown on NB medium were aseptically inoculated on Sulfide indole motility (SIM) medium (HiMedia Laboratories, India) containing tubes followed by incubation at $37^{\circ} \mathrm{C}$. The development of ferrous sulfide (black ppt.) confirmed the positive test results. Oxidase tests were carried out as described by Hayward (1960). In this test, $24 \mathrm{~h}$ old bacterial culture was mixed with a few drops of $1 \%$ $\mathrm{N}, \mathrm{N}, \mathrm{N}^{\prime}, \mathrm{N}^{\prime}$-tetramethyl-p-phenylenediamine (TMPD) solution (Sigma-Aldrich, United States) on Whatman No. 1 filter paper. The appearance of a dark purple color within $30 \mathrm{~s}$ confirmed the positive test results. The test for oxidative fermentation was performed as described by Hugh and Leifson (1953), while nitrate reduction and gelatin hydrolysis assays were carried out using the protocol previously used by Thankamani and Dev (2011).

\section{Molecular Characterization of Rhizobacterial Isolates}

Bacterial agents displaying promising antagonistic activity were identified using 16S rRNA gene sequencing (Kumar et al., 2015). Total genomic DNA was extracted from bacterial 
isolates, by using the GeneJet Genomic DNA purification Kit (Thermo Scientific Waltham, United States) following the manufacturer's instructions. The $16 \mathrm{~S}$ rRNA region was amplified in a polymerase chain reaction (PCR) using primer pair $27 \mathrm{~F}$ [5' -AGAGTTTGATC-MTGGCTCAG- 3'] and 1492R [5 GGTTACCTTGTTAC-GACTT- $3^{\prime}$ ], respectively (Habib et al., 2016), in $50 \mu \mathrm{l}$ reactions consisting 25-150 ng of DNA template, $1 \mathrm{X}$ of Taq buffer (10 mM Tris $\mathrm{pH} 9,50 \mathrm{mM} \mathrm{KCl}, 0.01 \%$ gelatin), $200 \mu \mathrm{M}$ of each dNTP, $1.25 \mathrm{mM}$ of $\mathrm{MgCl}_{2}, 0.4 \mu \mathrm{M}$ of each primer, and $0.5 \mathrm{U}$ of Taq DNA polymerase (Qiagen, Germany).

Polymerase chain reaction conditions were: initial denaturation of DNA template at $95^{\circ} \mathrm{C}$ for $1 \mathrm{~min}$ per cycle, 35 cycles of denaturation at $95^{\circ} \mathrm{C}$ for $15 \mathrm{~s}$, annealing at $55^{\circ} \mathrm{C}$ for $15 \mathrm{~s}$, extension at $72^{\circ} \mathrm{C}$ for $1 \mathrm{~min}$ and a final elongation at $72^{\circ} \mathrm{C}$ for $7 \mathrm{~min}$. Amplified DNA products were then run on $1 \%$ (w/v) agarose gel and visualized under UV transilluminator after staining with Ethidium bromide (EB). PCR products $(1.5 \mathrm{~Kb})$ of $16 \mathrm{~S}$ rRNA gene were cleaned with Gel and PCR Clean-Up System (Promega, United States), and quantified by NenoDrop.

The amplified DNA products were then sent for sequencing to the Department of Crop Sciences, University of Illinois, Urbana, IL, United States. Frequents were sequenced using 27F and 1492R primers, and obtained sequences were joined by Bioinformatics software for life science (DNASTAR software). Sequences were run in the BLAST program $^{1}$ at the National Center for Biotechnology Information (NCBI) server to search the closely related sequences. All the retrieved sequences along with tested bacterial isolates sequences were aligned together using CLUSTAL W Program.

The evolutionary relatedness between the tested bacterial sequences and retrieved sequences was determined by constructing a phylogenetic tree using the neighbor-Joining $(\mathrm{N}-\mathrm{J})$ method in Molecular Evolutionary Genetics Analysis software MEGA X version 10.1 .7 with 1000 bootstrap replicates. The evolutionary distances were calculated using the Kumara 2-parameter model (K2 + G) (Kumar et al., 2018). The 16S rRNA gene sequences were deposited in the GenBank nucleotide database and accession numbers were obtained.

\section{CHARACTERIZATION OF ISOLATED BACTERIAL STRAIN FOR PLANT GROWTH PROMOTING TRAITS}

\section{Ammonia $\left(\mathrm{NH}_{3}\right)$ Production}

The production of $\mathrm{NH}_{3}$ was tested in accordance with Cappuccino and Sherman (2005). In particular, $24 \mathrm{~h}$ old each bacterial isolate $(100 \mu \mathrm{l})$, grown on nutrient broth medium was inoculated on test tubes containing peptone water $(10.0 \mathrm{~g}$ peptone; $5.0 \mathrm{~g} \mathrm{NaCl} ; 1000 \mathrm{~mL}$ distilled water; $7.0 \mathrm{pH}$ ) and incubated at $28^{\circ} \mathrm{C}$ for $48-72$ h. $500 \mu \mathrm{l}$ of Nessler's reagent (Fisher ${ }^{\circledR}$, United States) was added to each test tube. Brown to yellow color development confirmed the $\mathrm{NH}_{3}$ production.

${ }^{1}$ https://blast.ncbi.nlm.nih.gov

\section{Starch Hydrolysis}

A starch hydrolysis test was performed using the protocol previously described (Marten et al., 2000). In particular, 24 h old bacteria were cultured on LB agar medium containing Petri plates amended with $2 \%$ starch and incubated at $30 \pm 2{ }^{\circ} \mathrm{C}$ for $48-72 \mathrm{~h}$. Plates were then flooded with Lugol's solution. Clear halo zone formation around the bacterial growth confirmed the positive test results of starch hydrolysis.

\section{Phosphate Solubilization}

Phosphate solubilizing ability was assessed by following the procedure previously reported by Verma et al. (2001). For this test, the bacterial cultures were streaked on Pikovskaya's agar medium (HiMedia Laboratories, India) and supplied with tricalcium phosphate in Petri plates. Plates were then incubated at $28 \pm 2{ }^{\circ} \mathrm{C}$ for $72-96 \mathrm{~h}$. The formation of clear halo zones encircling the bacterial colonies indicated phosphate solubilization. Phosphate solubilization was quantified by Phosphomolybdate blue color assay as previously described by Murphy and Riley (1962).

\section{Hydrogen Cyanide}

Production of HCN was assessed by adopting the procedure reported by Lorck (1948). In this test, $24 \mathrm{~h}$ old bacterial strains were streaked on NA medium containing Petri plates amended with glycine $\left(4.4 \mathrm{gL}^{-1}\right)$. Agar medium was covered with Whatman number 1 filter paper previously dipped in a solution of $0.5 \%$ picric acid and $2 \%$ sodium carbonate $(\mathrm{w} / \mathrm{v})$. Petri plates were Parafilmed, and incubated at $28 \pm 2^{\circ} \mathrm{C}$ for $96 \mathrm{~h}$. The development of an orange or red color indicated $\mathrm{HCN}$ production.

\section{Indole Acetic Acid (IAA) Detection and Quantification}

Bacterial isolates were inoculated on LB medium amended with $0.5 \mathrm{mgL}^{-1}$ tryptophan $/ \mathrm{mL}$, incubated at $28 \pm 2{ }^{\circ} \mathrm{C}$ for 5 days, and centrifuged at 3,000 rpm for $30 \mathrm{~min}$. The supernatant $(2 \mathrm{~mL}$ of the aliquot) was added with two drops of orthophosphoric acid and $4 \mathrm{~mL}$ of Salkowaski's reagent $(150 \mathrm{~mL}$ concentrated $\mathrm{H}_{2} \mathrm{SO}_{4}, 250 \mathrm{~mL}$ distilled water, $\left.7.5 \mathrm{~mL} 0.5 \mathrm{M} \mathrm{FeCl}_{3} .6 \mathrm{H}_{2} \mathrm{O}\right)$, and incubated at room temperature in dark for $20 \mathrm{~min}$ (Gordon and Weber, 1951). The development of a pink-red color indicated the production of IAA. The absorbance of IAA was recorded at $530 \mathrm{~nm}$ using a spectrophotometer (Thermo Scientific, United States) and the concentration of IAA was measured against a standard curve developed from pure IAA solution. There were three replications for each bacterial isolate, and all the mean values were statistically analyzed.

\section{Siderophores Production}

Siderophores production was tested in accordance with Schwyn and Neilands (1987). In particular, the siderophores production test was performed by culturing bacterial isolates $\left(10^{8} \mathrm{cfu} \mathrm{mL}^{-1}\right)$ on Chrome azurol $\mathrm{S}$ agar medium followed by incubation at $28 \pm 2{ }^{\circ} \mathrm{C}$ for $72 \mathrm{~h}$. Change in the color from yellow to orange was an indication of siderophores production. Siderophores production was quantified by CAS-liquid assay (Payne, 1994); 
Optical density (OD) was measured at $630 \mathrm{~nm}$ against a reference consisting of CAS reagent. Siderophore contents were calculated by the formula:

$$
\% \text { siderophore unit }=\frac{\mathrm{Ar}-\mathrm{As}}{\mathrm{Ar}} \times 100
$$

Ar $=$ absorbance of the standard at $630 \mathrm{~nm}$.

As $=$ absorbance of the sample at $630 \mathrm{~nm}$.

\section{Multiple Antibiotic Resistance of Rhizobacterial Isolates}

Multiple antibiotic resistance tests were performed to check the level of susceptibility and resistance of rhizobacterial isolates by following the methodology previously described by Singh et al. (2013). The test was performed to screen the bacterial isolates against streptomyces, ampicillin, rifampicin, penicillin $G$, and vancomycin at different concentration levels $(0 \mathrm{ppm}, 100 \mathrm{ppm}$, $200 \mathrm{ppm}, 300 \mathrm{ppm}, 400 \mathrm{ppm}$, and $500 \mathrm{ppm}$ ) in vitro. For this, $100 \mu \mathrm{l}$ of $24 \mathrm{~h}$ old bacterial suspensions prepared in NB medium were spread on Petri plates containing solid NA medium. Small filter paper disks immersed in each antibiotic concentration were placed on the media and plates were incubated at $26 \pm 2{ }^{\circ} \mathrm{C}$ for $24 \mathrm{~h}$. Each treatment was replicated five times and the zone of inhibition was measured from each treatment.

\section{IN-PLANTA ASSAYS}

\section{Effect of Seed Bacterization on Germination and Vigor Index in Chili}

For this, chili seeds (variety: Long green) were bacterized by immersing surface sterilized seeds in $24 \mathrm{~h}$ old bacterial inoculum prepared in $25 \mathrm{~mL} \mathrm{LB}$ medium (bacterial concentrations $10^{6}, 10^{7}$, and $10^{8} \mathrm{cfu} \mathrm{mL}^{-1}$ ) by gently shaking on a shaker for $2 \mathrm{~h}$. Ten seeds/Petri plates were placed on two layers of moistened filter paper in each 9 -cm plate and were incubated at $28 \pm 2^{\circ} \mathrm{C}$ in the growth room (Seleim et al., 2011). Filter papers were kept moist by adding $5 \mathrm{~mL}$ autoclaved distilled water when needed. Seeds soaked in only autoclaved distilled water were kept as control. Data on growth parameters and vigor index was recorded after 20 days of incubation. The experiment was performed with five replications for each treatment. Seed germination percentage (GP) and vigor index (VI) were recorded by the formulas:

$$
\text { Seed germination }(\%)=\frac{\text { No. of germinated seeds }}{\text { total no. of seeds }} \text { X } 100
$$

Vigor index $=\%$ seed germination $\mathrm{X}$ total plant length

\section{Evaluation of Bacterial Isolates for the Induction of Defense Related Enzymes}

Bacterial antagonists were evaluated for defense related enzyme induction ability in a pot experiment on chili (variety: Long green) under natural conditions in a net house. Plastic pots of $1.5 \mathrm{~L}$ capacity were filled with autoclaved sandy loam textured soil and flooded with $20 \mathrm{~mL}$ sporangial suspension of $P$. myriotylum $\left(1 \times 10^{3}\right.$ sporangia/mL). Fifteen days old healthy seedlings were dipped for $2 \mathrm{~h}$ in overnight bacterial suspension $\left(10^{8} \mathrm{cfu} / \mathrm{mL}\right)$ in LB medium before shifting in pots containing infested soil. Five seedlings per pot were sown in three repeats and placed under net house conditions at $28 \pm 2{ }^{\circ} \mathrm{C}$ and $80 \%$ relative humidity. The experiment was performed with ten treatments viz., T1 (P. myriotylum as negative control), T2 (4a2 - Flavobacterium spp.), T3 (JHL-8 - Bacillus megaterium), T4 (JHL-12 - P. putida) T5 (1C2 - B. cereus), T6 (RH-24 - B. subtilis), T7 (1D - B. cereus), T8 (5C - P. putida) T9 (RH-87 - P. libanensis) T10 (Untreated control) in three repeats. Root tissues were taken at 1, 3 and, 5 days intervals after transplant.

\section{Enzyme Extraction and Quantification}

Representative chili root samples ( $2 \mathrm{~g}$ ) were crushed with $4 \mathrm{~mL}$ of $0.1 \mathrm{M}$ sodium phosphate buffer at $4^{\circ} \mathrm{C}$ in sterilized mortar and pestle. The homogenized solution was centrifuged for $15 \mathrm{~min}$ at $10,000 \mathrm{rpm}$ and $4^{\circ} \mathrm{C}$ and supernatant was used for the estimation of PO, PPO, PAL, and chitinase activity by spectrophotometry (Anand et al., 2007).

\section{Peroxidase Test (PO)}

Peroxidase test activity was tested by following the methodology adopted by Hammerschmidt et al. (1982). In this test, peroxidase activity was measured by mixing $0.5 \mathrm{~mL}$ of enzyme extract with $1.5 \mathrm{~mL}$ of pyrogallol $(0.05 \mathrm{M})$ and $0.5 \mathrm{~mL}$ of $1 \% \mathrm{H}_{2} \mathrm{O}_{2}$ and incubated at room temperature. The absorbance change was noted at $420 \mathrm{~nm}$ at $30 \mathrm{~s}$ intervals for 3 min against a blank.

\section{Polyphenol Oxidase Test}

Polyphenol oxidase test was performed in accordance with the methodology described by Mayer et al. (1966). In particular, PPO activity was determined by mixing $200 \mathrm{~mL}$ of the crude enzyme extract with $1.5 \mathrm{~mL}$ of $0.1 \mathrm{M}$ sodium phosphate buffer, $200 \mathrm{~mL}$ of $0.01 \mathrm{M}$ catechol was added to start the reaction, and absorbance was recorded at $495 \mathrm{~nm}$ wavelength.

\section{Phenylalanine Ammonialyas Test (PAL)}

A PAL activity test was performed in accordance with Whetten and Sederoff (1992). In particular, PAL activity was assessed by mixing $100 \mu \mathrm{l}$ of enzyme, $500 \mu \mathrm{l}$ of $50 \mathrm{mM}$ Tris HCL, and $600 \mu \mathrm{l}$ of $1 \mathrm{mM}$ L-phenylalanine followed by incubation for $1 \mathrm{~h}$. The reaction was stopped by adding with $2 \mathrm{~N}$ HCL followed by adding $1.5 \mathrm{~mL}$ toluene in the mixture, vortexed for $30 \mathrm{~s}$, and centrifugation at $1000 \mathrm{rpm}$ for $5 \mathrm{~min}$. Toluene fraction carrying trans-cinnamic acid was separated. The toluene phase was estimated at $290 \mathrm{~nm}$ wavelength against the toluene as blank, and a standard curve was constructed with graded amounts of cinnamic acid in toluene.

\section{Testing of Bacteria for Disease Suppression and Plant Growth Promotion (PGP) Traits in Pot Trials}

The potential of antagonistic bacteria to suppress the dampingoff disease and plant growth promotion effect was tested under 
natural environmental conditions in net house conditions in a repeated experiment. In this study, zoospores of $P$. myriotylum were obtained by following the procedure previously described by Rahimian and Banihashemi (1979), and concentration was maintained at $1 \times 10^{6}$ zoospores/mL using a hemocytometer. Plastic pots $(1.5 \mathrm{~L})$ were filled with sterilized soil/peat $(75 \%$ : $25 \%$ ratio) and $100 \mathrm{~mL}$ zoospore suspension of $P$. myriotylum was added in the soil before sowing the chili seeds (Variety: Long green). Prior to sowing, surface sterilized chili seeds were soaked individually for $2 \mathrm{~h}$ in bacterial suspensions $\left(10^{8}\right.$ $\mathrm{cfu} / \mathrm{mL}$ ) prepared in Luria-Bertani (LB) medium (Sigma-Aldrich, United States). Un-inoculated seeds without P. myriotylum and rhizobacteria were kept as untreated control (UTC) while the seeds inoculated with $P$. myriotylum were kept as a negative control (NC). All other plant management practices were kept the same for all the treatments. Experiments were carried out with five replications for each treatment. Pots were kept under net house conditions and damping-off disease incidence and seed germination percentage were recorded after 15 days of sowing while data on PGP was taken 30 days after sowing the seeds.

\section{Statistical Data Analysis}

Statistical data analysis was performed using Statistix 8.1 software and MS Excel 2010. All the experiments were performed in a completely randomized design (CRD) with replicated treatments. All the experiments were repeated at least two times to confirm the results. Mean values for each treatment were calculated, and all the treatment means were compared via the Analysis of variance (ANOVA) test using the least significant differences (LSD) at $5 \%$ probability $(P \leq 0.05)$. The correlation was studied in Microsoft Office Excel 2010.

\section{RESULTS}

\section{Pathogen Inoculum of $P$. myriotylum}

A total of 13 isolates of $P$. myriotylum were recovered from infected chili roots showing characteristic symptoms of dampingoff disease on corn meal agar medium (CMA). They were identified based on morphological characters, i.e., coenocytic hyphae bearing lobate sporangia (7 to $15 \mu \mathrm{m}$ wide), knoblike appressorium, vesicles (43 to $52 \mu \mathrm{m}$ in diameter) bearing 29 to 45 zoospores/vesicle, encysted zoospores (10 to $12 \mu \mathrm{m}$ in diameter), terminal oogonia (30 to $38 \mu \mathrm{m}$ in diameter), crooked necked antheridia (4 to 7 antheridia per oogonium), and aplerotic oospores (25 to $31 \mu \mathrm{m}$ in diameter) as presented in Figure 1. Internal transcribed spacer regions (ITS1 and ITS2) were amplified by PCR and final sequences were submitted to the GenBank database under the accessions MF143429 and MF143430. BLAST analysis of approximately 700 bp fragments showed $99 \%$ sequence identity with an already published sequence of $P$. myriotylum (accession HQ643704). Both the isolates PMyr-1 and PMyr-2 produced characteristic dampingoff symptoms in pathogenicity tests on chili. This pathogen was previously described in the first report on $P$. myriotylum causing damping-off and root rot in chili from Punjab, Pakistan.

\section{Isolation and in vitro Screening of Bacterial Isolates Against $P$. myriotylum}

A total of 110 rhizobacterial isolates were recovered from the healthy chili roots and rhizospheric soil samples and were screened for antagonistic potential against two highly virulent strains of $P$. myriotylum (PMyr-1 and PMyr-2) isolates in repeated dual culture experiments on the PDA medium. Out of all tested isolates, 28 (25.5\%) bacterial isolates exhibited varied levels of antagonistic activities (Unpublished data). Data recorded after 48 and $96 \mathrm{~h}$ of incubation showed that out of 28 bacterial isolates, 8 (28.6\%) rhizobacteria; Flavobacterium spp., Bacillus megaterium, Pseudomonas putida, B. cereus, B. subtilis, $B$. cereus, $P$. putida, and $P$. libanensis exhibited significant antagonistic activity against $P$. myriotylum as compared to control under in vitro conditions (Figure 2). Forty-eight hours after inoculation, mycelial growth inhibition percentage in PMyr1 was ranged from 38.6 to $81.4 \%$ ( $48 \mathrm{~h}$ after inoculation) and 36.1 to $76.7 \%$ (96 h after inoculation), while percentage mycelial growth inhibition in PMyr-2 was 48.5 to $80.6 \%$ and 41.4 to $75.9 \%$ after 48 and 96 h of inoculation, respectively. These eight potential bacterial isolates were further tested by subsequent in vitro experiments.

\section{Biochemical Featuring of Rhizobacterial Isolates}

The response of all the tested bacterial isolates toward various biochemical tests is presented in Table 1 . Out of the eight bacterial isolates, four isolates B. megaterium, B. cereus, B. subtilis, and $B$. cereus were gram positive while three isolates gave fluorescence emission. Four bacteria including Flavobacterium spp., Pseudomonas putida, P. putida, and P. libanensis gave positive results for the $\mathrm{KOH}$ solubility test while all the bacteria isolates were positive for catalase production. In response to the levan production test, two bacterial isolates, $B$. cereus and $P$. libanensis showed positive test results while $P$. putida and $B$. cereus were positive for carbohydrate fermentation reaction. All the tested bacterial isolates showed positive results for the oxidase test except $P$. libanensis, which was not tested for the response. All the bacterial antagonists except $B$. subtilis exhibited a positive response in the oxidative fermentative test. All bacterial isolates except for Flavobacterium spp. gave positive results for the nitrate reduction and gelatin hydrolysis tests. Nitrate reduction and gelatin hydrolysis tests were not performed on P. libanensis and Flavobacterium spp. bacterial isolates, respectively.

\section{Molecular Characterization of Rhizobacterial Isolates}

Phylogenetic analysis from $16 \mathrm{~S}$ rRNA sequences $(\approx 1500 \mathrm{bp})$ of eight rhizobacterial isolates showed that all the tested bacteria belonged to Bacillus, Pseudomonas, and Flavobacterium spp. (Figure 3). Bacterial isolates ID and 1C2 had 97 to $98 \%$ sequence homology with Bacillus cereus (accessions MK606105 and MK648339, respectively) and the sequences of ID and 1C2 were submitted to the GenBank database under accession numbers MH393211 and MH393210.1, respectively. The 16S 

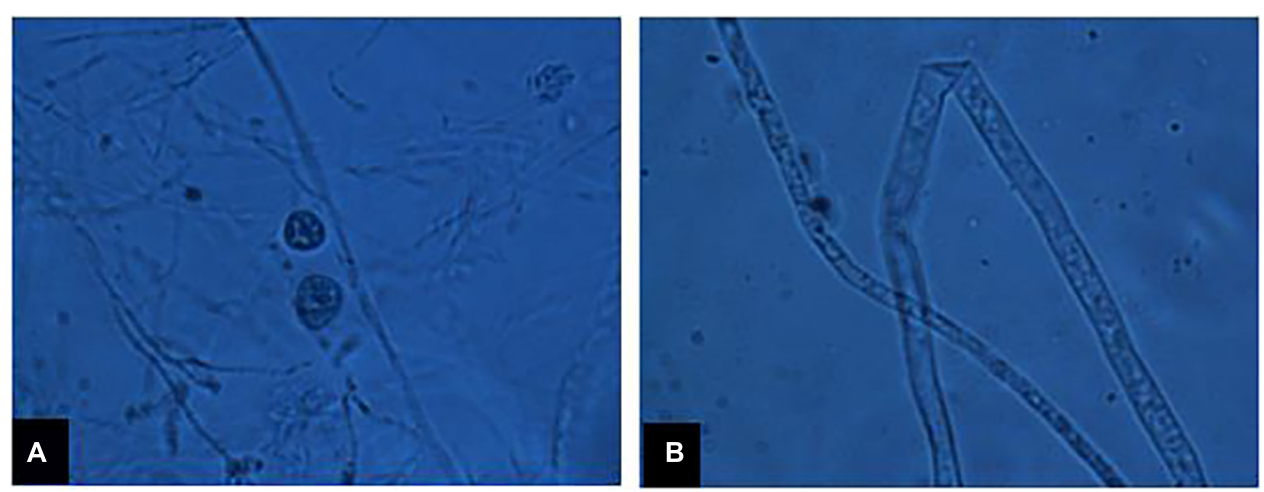

FIGURE 1 | (A) Sexual fruiting bodies of $P$. myriotylum, (B) coenocytic fungal hyphae under microscope.

rRNA gene sequence of the bacterial isolate JHL-8 (accession MH393209) showed 99\% sequence similarity with B. megaterium (accession MG430236). The sequence of RH-24 (accession

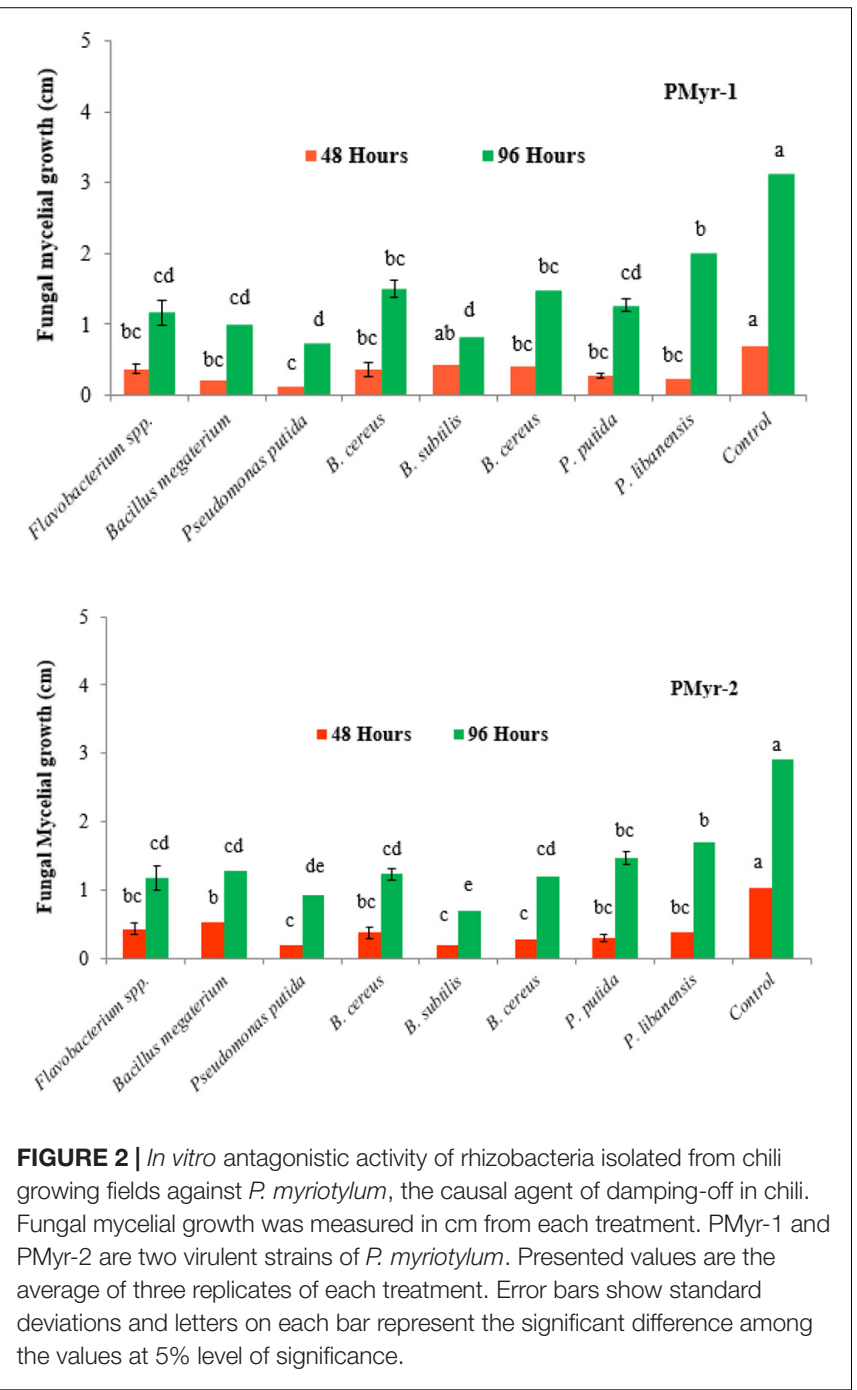

MH393208) had 99\% sequence homology with B. subtilis (accession KY000519). Isolate RH-87 (accession MT421780) was closely related to Pseudomonas libanensis 99\% identity with GenBank accession number DQ095905. Bacterial isolates 5C and JHL-12 had 99\% sequence homology with $P$. putida (accessions KY982927 and MF276642, respectively) and the sequences of $5 \mathrm{C}$ and JHL-12 were deposited to the GenBank database under accession numbers MH371201 and MH371200, respectively. Bacterial isolate $4 \mathrm{a} 2$ (accession MT421823) displayed 99\% identity with the GenBank sequence of Flavobacterium spp. (accession HM745136). The accession numbers of all the tested bacterial antagonists and sequence homology percentage with their reference isolates are given in Table 2.

\section{Characterization of Rhizobacterial Isolates for Biocontrol and Plant Growth Promotion (PGP) Traits}

All the rhizobacterial isolates were tested for biocontrol and plant growth promotion (PGP) traits and their responses are given in Table 3. All the bacterial isolates displayed positive test results for ammonia production as indicated by the brown to yellow color

TABLE 1 | Response of rhizobacteria isolated from chili growing fields to various biochemical tests.

\begin{tabular}{lcccccccccc} 
Bacterial isolates & GS & FE & KOH & CAT & LP & CF & OXD & OFR & NR & GH \\
\hline Flavobacterium spp. & - & - & + & + & - & - & + & + & - & NA \\
B. megaterium & + & - & - & + & - & - & + & + & + & + \\
P. putida & - & + & + & + & - & + & + & + & + & + \\
B. cereus & + & - & - & + & - & + & + & + & + & + \\
B. subtilis & + & - & - & + & - & - & + & - & + & + \\
B. cereus & + & - & - & + & + & + & + & + & + & + \\
P. putida & - & + & + & + & - & - & + & + & + & + \\
P. libanensis & - & + & + & + & + & - & NA & + & NA & + \\
\hline
\end{tabular}

*Each test result was confirmed in three replications for each bacterial isolate. (+) positive reaction (-) negative reaction and (NA) not tested results for: gram staining (GS), fluorescence emission (FE), potassium hydroxide (KOH), catalase test $(C A T)$, levan production $(L P)$, carbohydrate fermentation (CF), oxidase test (OXD), oxidative fermentative (OFR), nitrate reduction (NR), gelatin hydrolysis $(G H)$ test. 


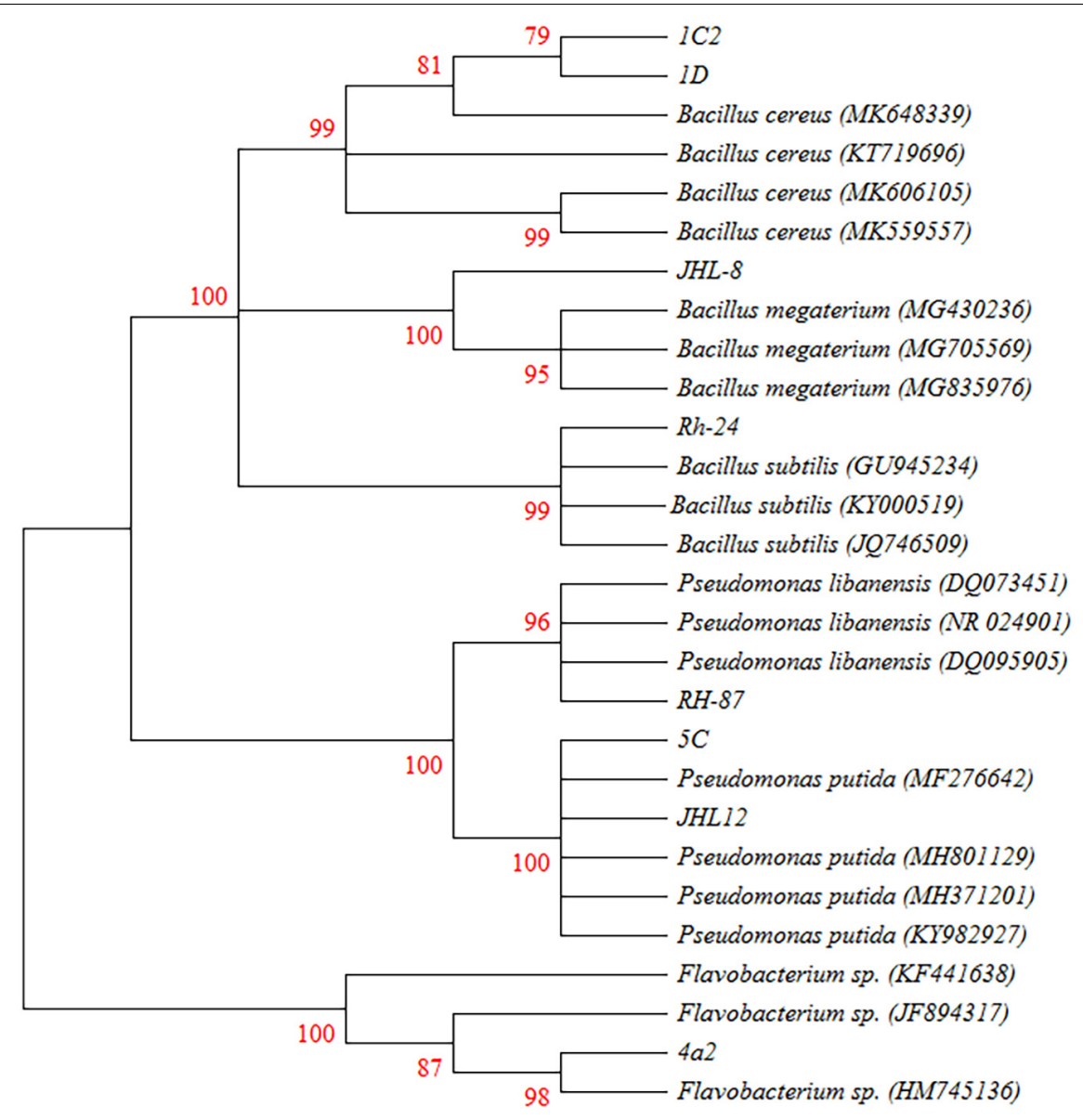

FIGURE 3 | Phylogenetic tree based on the 16 S rRNA sequences ( $\approx 1500$ bp) showing the relationships between the representative rhizobacteria and closely associated neighbors. 16s rRNA gene fragments were amplified by PCR protocols using 27F and 1492R primers and amplified products were confirmed by Gel electrophoresis against $1 \mathrm{~kb}$ ladder. Gel purified DNA products were sent for sequencing and obtained sequences were joined by using DNASTAR software. BLAST analysis was performed to retrieve closely associated bacterial sequences. All the Sequences were aligned in CLUSTAL W program and the phylogenetic tree was constructed using Kumara 2-parameter model (K2 + G) using 1000 replicates as bootstrap values and >70\% are labeled.

TABLE 2 | Sequence analysis of 16S rRNA from rhizobacteria isolated from chili growing fields and their homology with the reference bacteria.

\begin{tabular}{|c|c|c|c|c|c|}
\hline Isolate ID & Sequence (bp) & Accession No. & Identified As & Identity with Accession No. & Similarity Index \\
\hline Flavobacterium spp. & 1377 & MT421823 & Flavobacterium spp. & HM745136 & $99.7 \%$ \\
\hline B. megaterium & 948 & MH393209 & Bacillus megaterium & MG430236 & $99 \%$ \\
\hline P. putida & 1316 & MH371200 & Pseudomonas putida & MF276642 & $99 \%$ \\
\hline B. cereus & 938 & MH393210 & B. cereus & MK648339 & $98 \%$ \\
\hline B. subtilis & 1381 & MH393208 & B. subtilis & KY000519 & $99 \%$ \\
\hline B. cereus & 1088 & MH393211 & B. cereus & MK606105 & $97 \%$ \\
\hline P. putida & 1417 & MH371201 & P. putida & KY982927 & $99 \%$ \\
\hline P. libanensis & 1370 & MT421780 & P. libanensis & DQ095905 & $99 \%$ \\
\hline
\end{tabular}

development. All the bacterial isolates were able to hydrolase starch while the test was not performed for Flavobacterium spp. All the tested bacterial isolates except $B$. cereus exhibited positive test results for hydrogen cyanide $(\mathrm{HCN})$ production, and the said test was not performed for Flavobacterium spp. A halo zone formation around the bacterial growth on Pikovskaya's agar medium after $96 \mathrm{~h}$ indicated the positive test results for phosphate solubilization by the bacterial isolates. Bacillus spp. Bacillus megaterium showed the highest P-solubilization $\left(103 \mu \mathrm{gmL}^{-1}\right)$ followed by B. subtilis $\left(97 \mu \mathrm{gmL}^{-1}\right)$. In the case of Pseudomonas sp., $P$. putida exhibited maximum P-solubilization $\left(84 \mu \mathrm{gmL}^{-1}\right)$ followed by $P$. libanensis $\left(79 \mu \mathrm{gmL}^{-1}\right)$ and P. putida $\left(75 \mu \mathrm{gmL}^{-1}\right)$. Flavobacterium spp. showed maximum P-solubilization $\left(86 \mu \mathrm{gmL}^{-1}\right)$ and the test was not done for 
TABLE 3 | Characterization of rhizobacteria isolated from chili growing fields for plant growth promoting (PGP) traits.

\begin{tabular}{|c|c|c|c|c|c|c|}
\hline $\begin{array}{l}\text { Bacterial } \\
\text { isolates }\end{array}$ & $\mathbf{A P}$ & SH & $\mathrm{HCN}$ & $\begin{array}{c}\text { P- } \\
\text { Solubilization } \\
\left(\mu \mathrm{g} \mathrm{mL}^{-1}\right)\end{array}$ & $\begin{array}{c}\text { IAA } \\
\text { production } \\
\left(\mu \mathrm{g} \mathrm{mL}^{-1}\right)\end{array}$ & SDP (\%) \\
\hline $\begin{array}{l}\text { Flavobacterium } \\
\text { spp. }\end{array}$ & + & ND & ND & $86 \pm 4.33^{b}$ & $34.1 \pm 1.7^{a}$ & $18.5 \pm 1.1^{d}$ \\
\hline B. megaterium & + & + & + & $103 \pm 3.53^{a}$ & $26.7 \pm 2.3^{b}$ & $23.7 \pm 2.0^{b}$ \\
\hline P. putida & + & + & + & $75 \pm 2.89^{c}$ & $19.6 \pm 1.4^{\mathrm{c}}$ & $17.3 \pm 1.4^{d}$ \\
\hline B. cereus & + & + & + & $81 \pm 3.28^{b c}$ & $13.9 \pm 1.7^{\mathrm{cd}}$ & $23.3 \pm 0.8^{b c}$ \\
\hline B. subtilis & + & + & + & $97 \pm 4.36^{a}$ & $39.0 \pm 1.5^{\mathrm{a}}$ & $27.7 \pm 1.5^{\mathrm{a}}$ \\
\hline B. cereus & + & + & - & ND & $19.3 \pm 2.8^{\mathrm{cd}}$ & $17.1 \pm 0.9^{d}$ \\
\hline P. putida & + & + & + & $84 \pm 2.31^{b c}$ & $26.7 \pm 2.2^{b}$ & $19.0 \pm 1.7^{\mathrm{cd}}$ \\
\hline P. libanensis & + & + & + & $79 \pm 3.93^{\mathrm{bc}}$ & $13.4 \pm 1.5^{d}$ & $23.6 \pm 1.6^{a b}$ \\
\hline LSD & & & & 10.062 & 5.8787 & 4.2705 \\
\hline
\end{tabular}

(+) positive (-) negative test, AP (ammonia production), SH (starch hydrolase), HCN (hydrogen cyanide production), PHS (phosphate solubilization), IAA (indole acetic Acid production), SDP (siderophore production \%). Data are average values of three replicates for each bacterial isolate. ( \pm ) standard error values.

bacterial isolate $B$. cereus. All the bacterial isolates showed pink-red color development as an indication of IAA production. The spectrophotometry study confirmed the production of IAA by bacterial isolates between 39 and $13.4 \mu \mathrm{gmL}^{-1}$. Maximum IAA $\left(39 \mu \mathrm{gmL}^{-1}\right.$ ) was produced by $B$. subtilis followed by Flavobacterium spp. (34.1 $\left.\mu \mathrm{g} \mathrm{mL}^{-1}\right), B$. megaterium and P. putida $\left(26.7 \mu \mathrm{gmL}^{-1}\right)$ while the minimum amount of IAA (13.4 $\mu \mathrm{gmL}^{-1}$ ) was produced by $P$. libanensis. Siderophore production was indicated by the change in color from blue to orange on chrome azurol S agar medium. Bacillus. subtilis showed the highest siderophore production (27.7\%) followed by B. megaterium (23.7\%) and B. cereus (23.3\%). P. libanensis showed the highest siderophores production $(23.6 \%)$ and P. putida (19\%) while Flavobacterium spp. showed $18.5 \%$ siderophores production.

\section{Multiple Antibiotic Resistance of Rhizobacterial Isolates}

All the bacteria displayed varying levels of resistance and susceptibility against all tested antibiotics (Figure 4) and zone of inhibition around the bacterial cultures were measured (Figures 5A-E). All the rhizobacterial isolates showed no tolerance against Streptomyces at all dose levels except Bacillus subtilis, which showed resistance up to $400 \mathrm{ppm}$ dose level. Against Ampicillin, all the tested bacteria showed resistance to all the dose levels except $B$. cereus and P. libanensis which showed little susceptibility at the two highest dose levels. When tested against Penicillin G, bacterial isolates, B. subtilis, P. putida, B. cereus, Flavobacterium spp., B. megaterium, and P. putida were found to have resistance at all the dose levels while $B$. cereus and $P$. libanensis showed little susceptibility at a $500 \mathrm{ppm}$ dose level. Most of the tested bacteria showed no resistance against Rifampicin at all six dose levels, however, B. subtilis showed resistance against Rifampicin up to $300 \mathrm{ppm}$ dose level and Flavobacterium spp. showed little susceptibility against Rifampicin at $500 \mathrm{ppm}$. Bacillus subtilis showed the highest tolerance against Vancomycin at all the dose levels while all other tested bacterial isolates showed varying levels of susceptibility response at different dose levels. The tested isolates ID, B. cereus and $P$. libanensis showed resistance response up to 300 ppm dose level of Vancomycin while the bacterial isolates Flavobacterium spp., B. megaterium, and P. putida showed maximum susceptibility.

\section{IN-PLANTA ASSAYS}

\section{Effect of Bacterial Inoculants on Chili Seed Germination}

The effect of bacterial seed treatment upon seed germination and plant growth parameters (PGP) varied with different bacterial isolates (Figures 6A-D). All the bacterial isolates produced significant effects on seed germination percentage and PGP compared to control treatment. None of the tested bacterial isolate at any applied concentration level showed a reduction in seedling germination and phytotoxic effects on chili seedlings. Maximum plumule length was recorded $11.8 \mathrm{~cm}$ in chili seedling inoculated with $B$. cereus at $10^{7} \mathrm{cfu}$ followed by $B$. subtilis $(9.6 \mathrm{~cm})$ over control. The maximum radical length was recorded $4 \mathrm{~cm}$ for $P$. putida at $10^{8} \mathrm{cfu}$ followed by $B$. cereus while the minimum radical length was recorded for $P$. libanensis at all the tested concentrations compared to control. Vigor index was significantly increased in bacterized chili seed over untreated control.

\section{Induction of Defense Related Enzymes in Chili Plants}

All the tested bacterial isolates significantly induced defense related enzymes in chili seedlings under the pathogen presence (Table 4). In chili seedlings treated with rhizobacterial suspensions, an increase in Peroxidase (PO) activity was observed 3 and 5 days after inoculation (DAI). Maximum PO activities were recorded in seedlings treated with Flavobacterium spp. followed by $B$. megaterium and $B$. subtilis and PO activates were recorded almost three folds higher than the negative control (NC) and untreated control (UC). The increased activity of Polyphenol oxidase (PPO) was observed on the fifth day after inoculation in seedlings treated with B. subtilis followed by Flavobacterium spp. and $P$. putida as compared to negative and untreated control. Phenylalanine ammonia-lyase (PAL) activities were observed high in all the chili seedlings treated with bacterial isolates. Maximum PAL activates were observed in seedlings inoculated with $B$. subtilis followed by $B$. megaterium and $B$. cereus. Phenylalanine ammonia-lyase (PAL) activities were recorded almost three-fold higher in all the bacterial treated seedlings compared to negative and untreated controls.

\section{Testing of Rhizobacterial Isolates for Disease Suppression and Plant Growth Promotion Traits in Pot Trials}

Considering the biocontrol and plant growth promotion traits, rhizobacterial isolates were screened for disease suppression 
and plant growth promotion in chili plants under an open environment, and data on disease suppression, seed germination, and plant growth traits were recorded. All the tested bacterial isolates significantly improved seed germination in the presence of pathogenic fungi in pot soil. Maximum seed germination of 96\% was produced by Bacillus subtilis followed by Flavobacterium spp. $(91 \%)$ and B. cereus $(89 \%)$ while B. megaterium showed the least effect on seed germination (70\%) over the negative control - NC (47\%). All the tested bacterial isolates suppressed the pathogenic fungi and significantly lower the seedling mortality ranging between 4.4 and $31 \%$ as compared to negative control where seedling mortality was recorded 53\% (Figure 7A). A significant increase in shoot length $(P \leq 0.05)$ was seen in all the treatments of bacterial isolates. A significant increase in shoot length $(24.4 \mathrm{~cm} /$ plant $)$ was observed in pots treated with B. subtilis followed by Flavobacterium spp. (18.4 cm/plant) over untreated control treatment-UTC $(11.1 \mathrm{~cm} /$ plant $)$ and negative control-NC $(5 \mathrm{~cm} /$ plant $)$. All the bacterial antagonists significantly enhanced the root length ranging $5.6-7.4 \mathrm{~cm} /$ plant over untreated control - UTC (5 cm/plant) and negative control $\mathrm{NC}$ where the root length was recorded $2.6 \mathrm{~cm} /$ plant (Figure 7B). An increase in fresh shoot weight $(P \leq 0.05)$ was observed in all the pots treated with bacteria isolates and an increase in fresh shoot weight ranged from 1.8 to 3.0 g compared to UTC (1.6 g) and NC $(1.1 \mathrm{~g})$. Data recorded from all the bacterial treated pots showed that the increase in the fresh root weight ranged between 0.96 and $2.3 \mathrm{~g}$ compared to un-inoculated pots $(0.93 \mathrm{~g})$ and the negative control $(0.4 \mathrm{~g})$, as given in Figure 7C. A significant increase in dry shoot weight $(P \leq 0.05)$ was also ranged from 1.1 to $2.1 \mathrm{~g}$ over un-inoculated pots $(0.93 \mathrm{~g})$ and negative control $(0.4 \mathrm{~g})$. Among all the tested isolates B. subtilis showed the highest increase in dry shoot weight $(2.1 \mathrm{~g})$ while P. libanensis showed the least significant increase in dry shoot weight $(1.1 \mathrm{~g})$. Data on dry root weight displayed that all the tested bacteria isolates had significantly increased the dry root weight $(P \leq 0.05)$ in chili plants ranging from 0.36 to $1.13 \mathrm{~g}$ over the untreated control $(0.46 \mathrm{~g})$ and negative control $(0.16 \mathrm{~g})$ (Figure $7 \mathrm{D})$. A positive correlation was observed between the shoot, root length, and dry

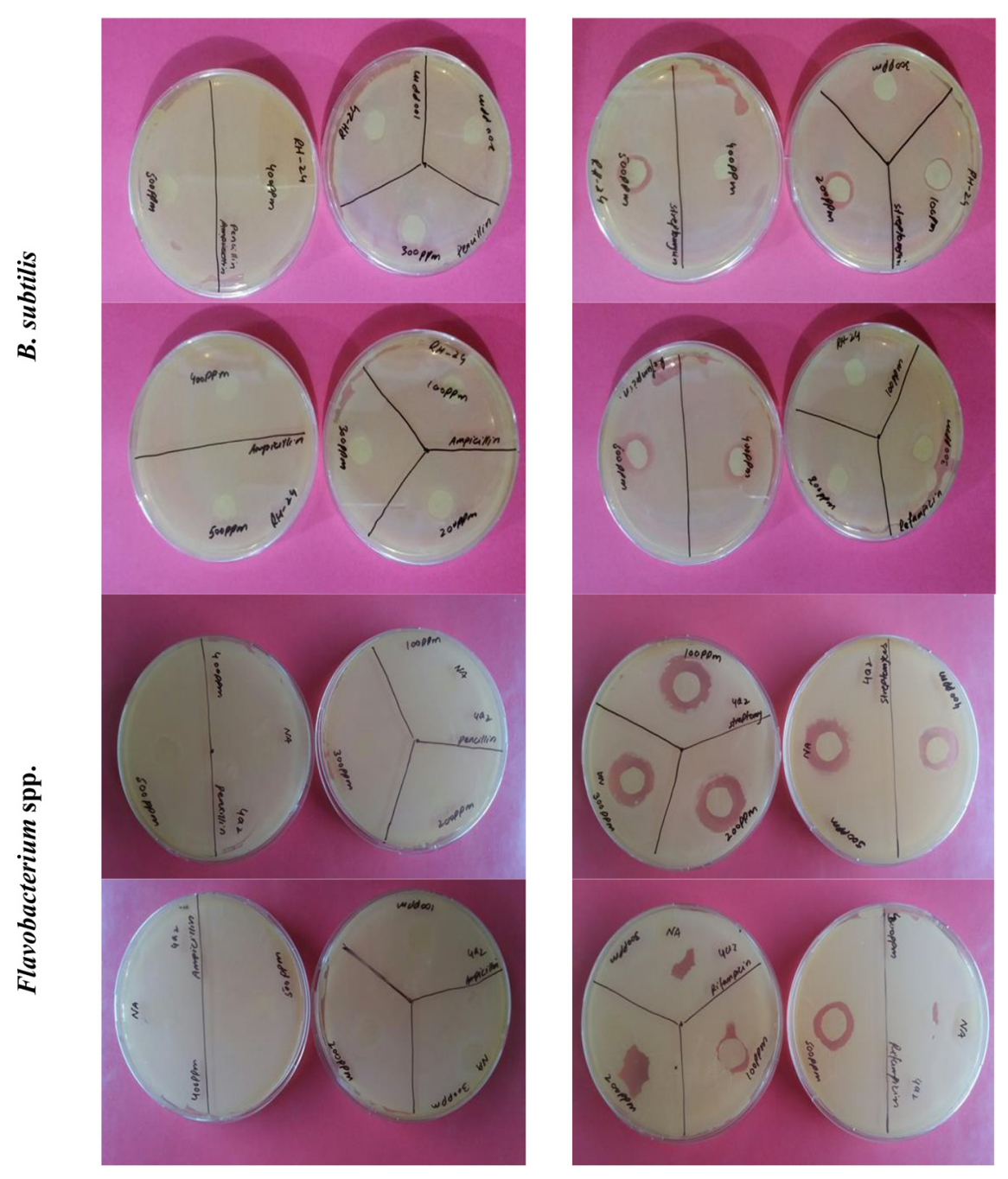

FIGURE 4 | Continued 


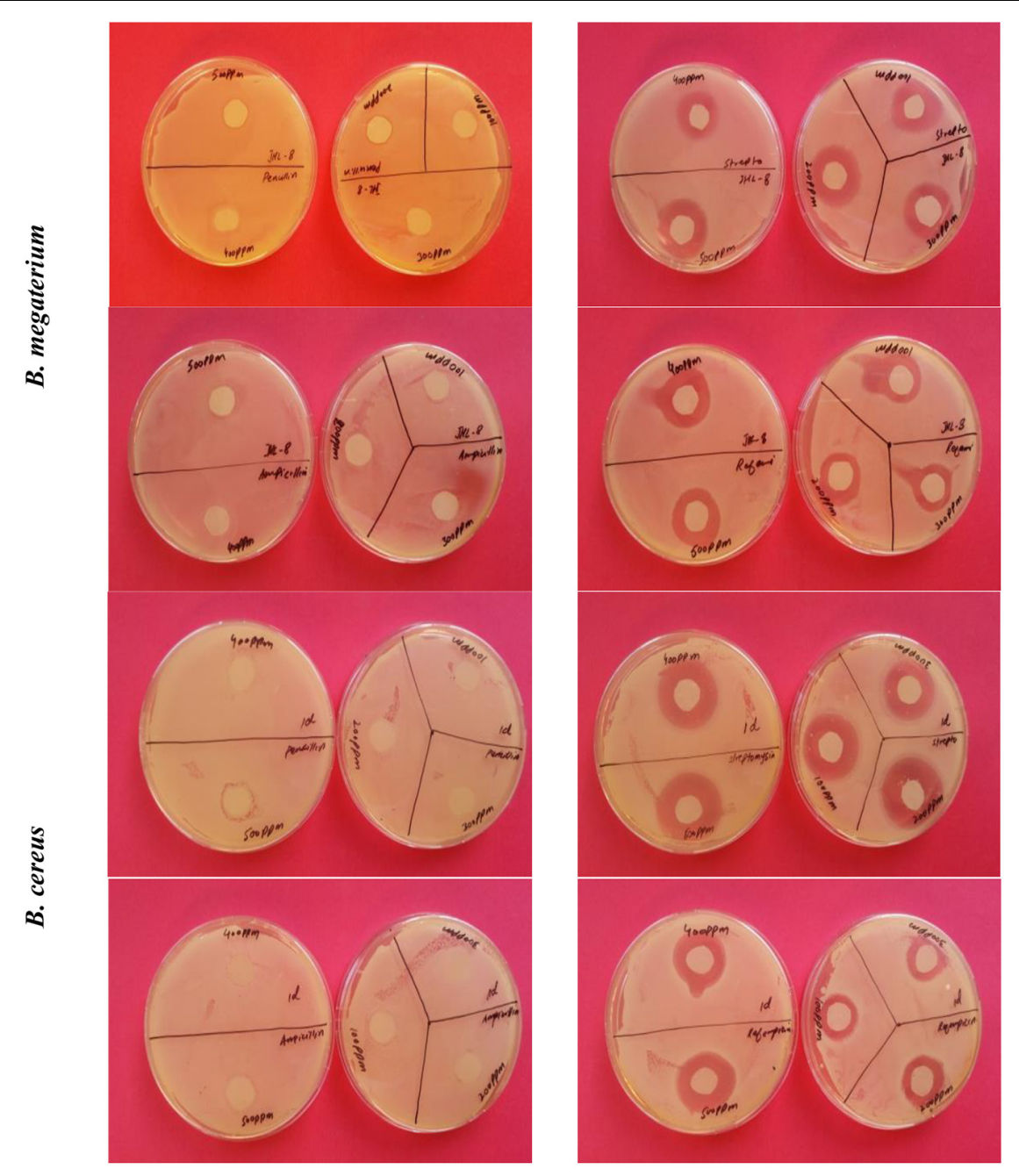

FIGURE 4 | Multiple antibiotic resistance assays to assess the resistance and susceptibility levels of rhizobacteria against Streptomyces, Ampicillin, Rifampicin, Penicillin G, and Vancomycin at 0, 100, 200, 300, 400, and 500 ppm concentrations. Zone of inhibition (cm) was measured from each replicated plate $24 \mathrm{~h}$ after incubation.

shoot, root weight (Figures 7E,F) whereas a negative correlation was recorded between dry shoot, root weight, and chili seedling mortality percentage (Figures $7 \mathrm{G}, \mathbf{H}$ ).

\section{DISCUSSION}

The damping-off of chili pepper by Pythium spp. causes decay of germinating seeds and growing seedlings at pre and post-emergence growth stages, and represents the huge yield constraints faced in both nurseries and field conditions (Erwin and Ribeiro, 1996). The estimated yield loss due to this disease could be from 5 to $80 \%$ under favorable conditions (Lamichhane et al., 2017). In our study, young symptomatic chili seedlings (15 to 30 days old) showed the damping-off, reduced growth, wilting, water soaked lesions, brown discoloration, and root rot due to Pythium infection. These symptoms confirm the findings of Horst (2013). A total of 13 Pythium isolates were recovered from these infections and were purified onto corn meal agar (CMA) medium amended with ampicillin $(250 \mathrm{mg} / \mathrm{L})$, rifampicin $(10 \mathrm{mg} / \mathrm{L})$, and pimaricin $(10 \mathrm{mg} / \mathrm{L})$ (Jeffers and Martin, 1986). The morphological features of these isolates including; coenocytic hyphae with lobate sporangia, knob-like appressorium, zoospores diameter, oogonia diameter, antheridia, and aplerotic oospores of the isolates fit well with descriptions of Pythium myriotylum Drechsler described in previous literature (Drechsler, 1943).

Seven day old fungal cultures were transferred to CMA medium for zoospore production by following the methodology previously described by Rahimian and Banihashemi (1979). The inoculum artificially applied to healthy plants under greenhouse conditions produced symptoms of damping-off and root rot compared to control plants that remained asymptomatic. This confirmed Koch's theory. The virulence of P. myriotylum has been reported in various studies (Kageyama and Ui, 1983; Okada, 2003; Tomioka et al., 2013). In another study, the pathogenicity of 

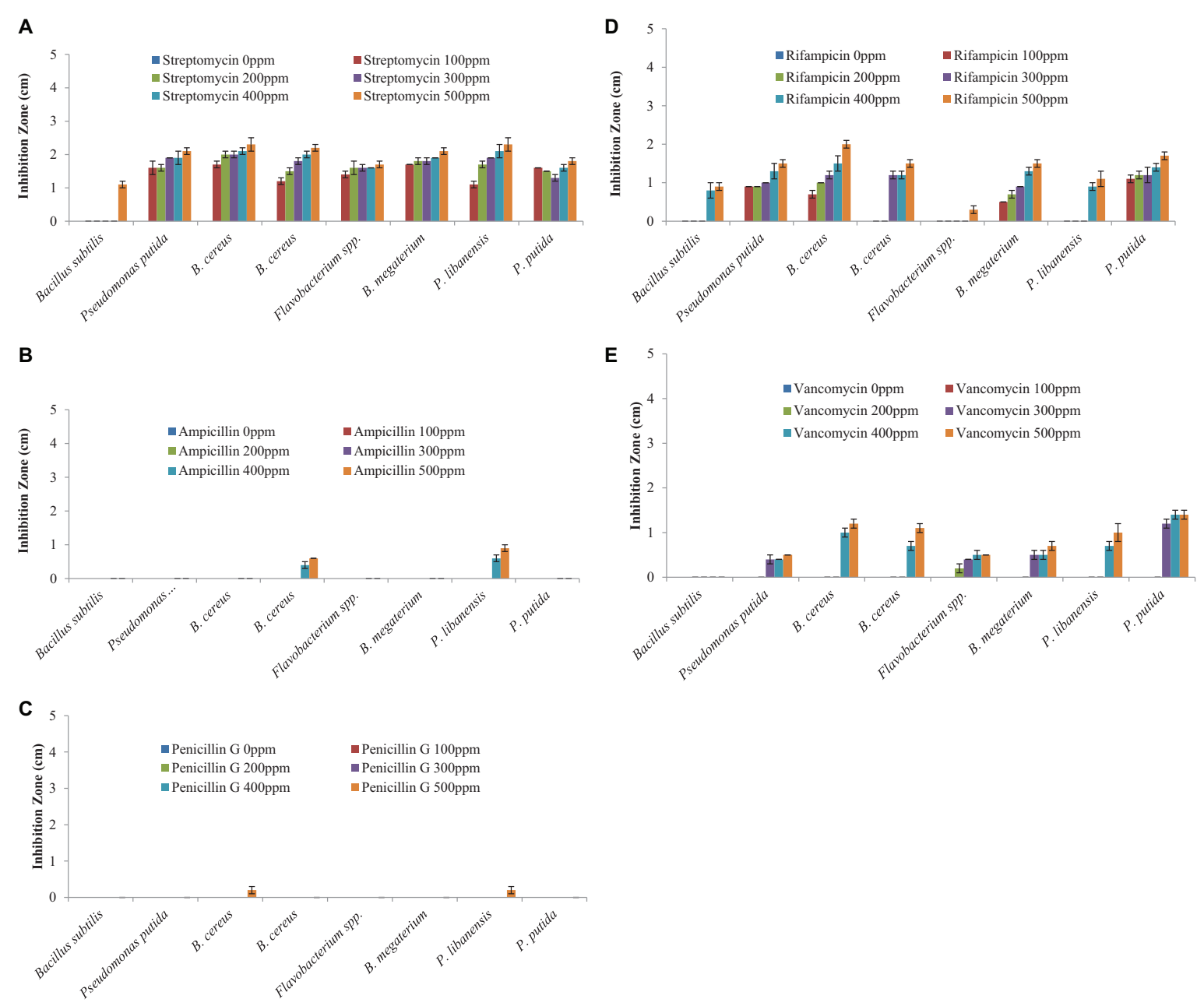

FIGURE 5 | Multiple antibiotic resistance assays to test the resistance and susceptibility levels of rhizobacteria against Streptomyces (A), Ampicillin (B), Rifampicin (C), Penicillin G (D), and Vancomycin (E) at six different concentration levels. Each treatment was tested in five replications and bar graphs are made by using average values for each treatment. Error bars on each bar represent the standard error (SE).

P. aphanidermatum was confirmed in tomato and chili seedlings by Ramamoorthy et al. (2002a). The two most aggressive isolates, PMyr-1 and PMyr-2, in pathogenicity trials were subjected to molecular characterization by amplifying the ITS1 and ITS2 regions as described by White et al. (1990). The amplified sequences of MF143429 and MF143430 (approximately 700-bp) showed 99\% sequence homology with HQ643704 accession of P. myriotylum previously described by Robideau et al. (2011). Similar results on molecular characterization of Pythium spp. were reported by Tomioka et al. (2013).

Among various disease management practices, chemical seed treatment has been adopted extensively (Rothrock et al., 2012; Kandel et al., 2016), and a variety of chemicals have been used as seed dressers to remove the pathogens from the seeds (Mancini and Romanazzi, 2014). However, chemical seed treatment adversely affects seed germination and can cause phytotoxicity (du Toit, 2004). Moreover, the non-judicial application of synthetic chemicals is a potential threat to human health and the environment (Ouyang et al., 2016), and is noxious to the beneficial rhizosphere microbes (Hussain et al., 2009), also resulting in the development of resistance in pests (Onstad, 2013), and increasing public security concerns in many countries (Bourguet and Guillemaud, 2016). Many of these chemicals are declared a carcinogen in a number of countries (Bressa et al., 1997). To minimize dependency on synthetic agrochemicals, scientists have devised alternative eco-friendly approaches to managing crop diseases more sustainably. Previous studies have highlighted the successful application of plant growth promoting rhizobacteria (PGPR) as an alternative to synthetic agrochemicals (Goudjal et al., 2014; Suwitchayanon et al., 2018; Miljaković et al., 2020).

The use of PGPR in disease suppression and plant growth promotion (PGP) is a widely adopted strategy in various crops such as wheat (Abbasi et al., 2011), rice (Yasmin et al., 2016), okra (Begum et al., 2012), cucumber (Islam et al., 2016), sweet pepper (Sid et al., 2003), red pepper (Lim, 2010), avocado (Cazorla et al., 2007), potato (Kenawy et al., 2019), and tomato (Szczech and Shoda, 2004). Souza 

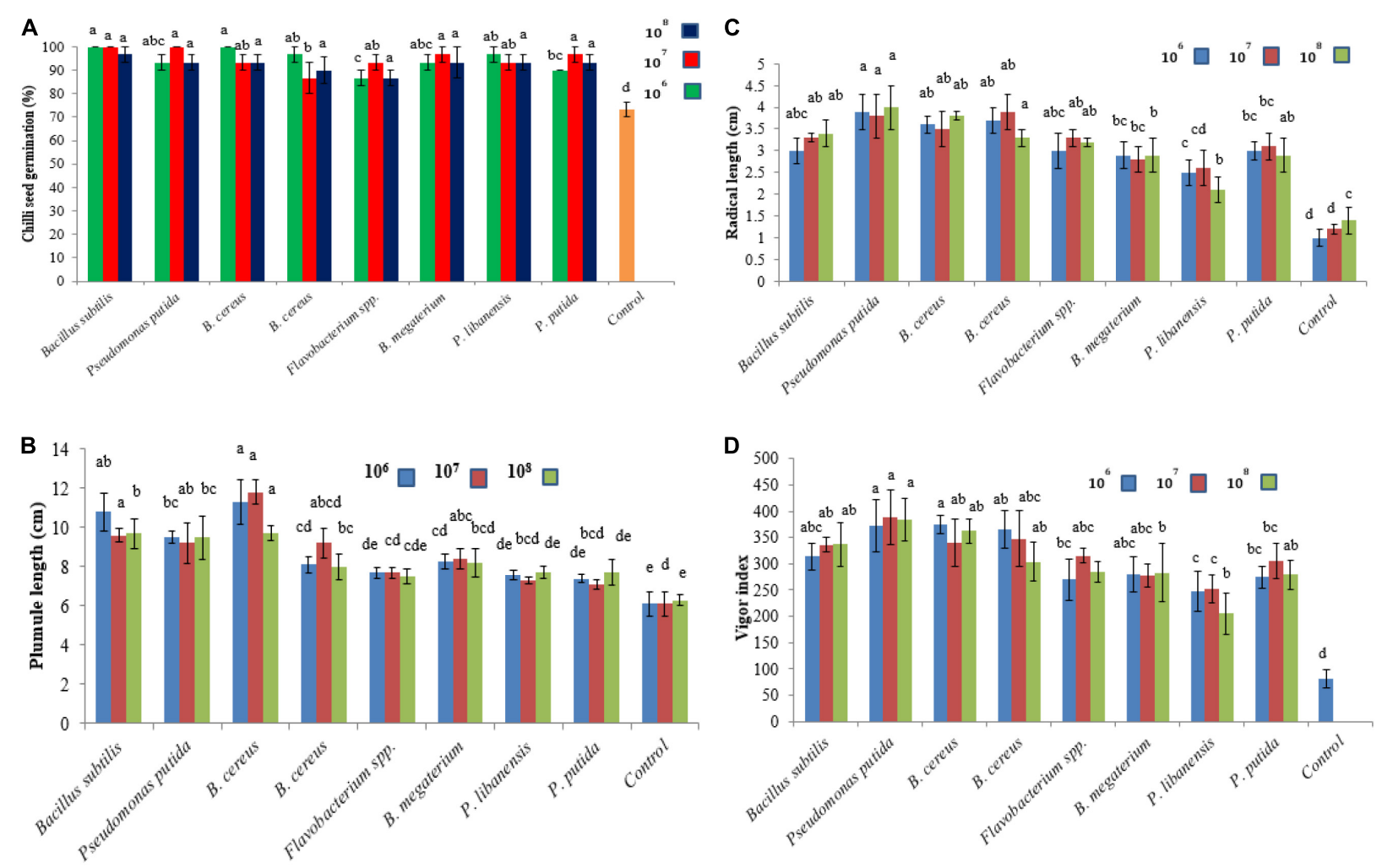

FIGURE 6 | Effect of rhizobacterial inoculants on chili seeds (A) seed germination percentage, (B) plumule length, (C) radical length, (D) vigor index. Chili seeds were treated with bacterial strains belonging to Flavobacterium spp. Pseudomonas spp. and Bacillus spp. while the seeds in the control treatment were dipped in double sterilized water only. Seeds were grown on moist Whatman filter paper No. 41 in sterile Petri plates under controlled conditions. Each treatment was replicated three times and bars are made from the average of three values. Error bars on each bar represent the standard error (SE).

TABLE 4 | Induction of defense related enzymes in chili seedlings inoculated with antagonistic rhizobacterial isolates.

\begin{tabular}{|c|c|c|c|c|c|c|c|c|c|}
\hline \multirow[t]{2}{*}{ Trt. } & \multicolumn{3}{|c|}{ PO activity (Katal/mg of total proteins) } & \multicolumn{3}{|c|}{ PPO activity (Katal/mg of total proteins) } & \multicolumn{3}{|c|}{ PAL activity (Katal/mg of total proteins) } \\
\hline & $1 \mathrm{DAl}$ & 3 DAl & 5 DAl & $1 \mathrm{DAl}$ & 3 DAI & 5 DAl & $1 \mathrm{DAl}$ & 3 DAl & 5 DAl \\
\hline NC & $0.23 \pm 0.03^{c}$ & $0.37 \pm 0.03^{c}$ & $0.33 \pm 0.03^{\mathrm{C}}$ & $0.13 \pm 0.03^{f}$ & $0.30 \pm 0.06^{d}$ & $0.40 \pm 0.06^{e}$ & $0.23 \pm 0.03^{a}$ & $0.37 \pm 0.07^{d}$ & $0.40 \pm 0.06^{\mathrm{e}}$ \\
\hline Flavobacterium spp. & $0.37 \pm 0.03^{a b}$ & $1.06 \pm 0.05^{\mathrm{a}}$ & $1.19 \pm 0.05^{\mathrm{a}}$ & $0.43 \pm 0.03^{b c}$ & $1.50 \pm 0.06^{b}$ & $1.77 \pm 0.19^{b}$ & $0.36 \pm 0.02^{a b}$ & $1.10 \pm 0.21^{b c}$ & $1.38 \pm 0.10^{\mathrm{cd}}$ \\
\hline B. megaterium & $0.33 \pm 0.03^{b c}$ & $0.93 \pm 0.03^{a}$ & $1.17 \pm 0.03^{a}$ & $0.45 \pm 0.08^{a b}$ & $1.33 \pm 0.09^{b}$ & $1.30 \pm 0.06^{c}$ & $0.44 \pm 0.07^{a}$ & $1.33 \pm 0.30^{\mathrm{abc}}$ & $1.67 \pm 0.14^{\mathrm{abc}}$ \\
\hline P. putida & $0.33 \pm 0.03^{b c}$ & $0.70 \pm 0.06^{b}$ & $0.87 \pm 0.03^{b}$ & $0.23 \pm 0.03^{\text {def }}$ & $1.53 \pm 0.12^{b}$ & $1.57 \pm 0.15^{b c}$ & $0.43 \pm 0.15^{a}$ & $1.42 \pm 0.10^{\mathrm{ab}}$ & $1.46 \pm 0.10^{b c}$ \\
\hline B. cereus & $0.30 \pm 0.06^{b c}$ & $0.67 \pm 0.03^{b}$ & $0.86 \pm 0.02^{b}$ & $0.20 \pm 0.06^{e f}$ & $1.57 \pm 0.22^{b}$ & $1.61 \pm 0.13^{b c}$ & $0.45 \pm 0.01^{a}$ & $1.53 \pm 0.23^{a b}$ & $1.75 \pm 0.14^{\mathrm{ab}}$ \\
\hline B. subtilis & $0.47 \pm 0.03^{a}$ & $1.03 \pm 0.03^{a}$ & $1.17 \pm 0.03^{a}$ & $0.60 \pm 0.06^{a}$ & $2.03 \pm 0.15^{a}$ & $2.43 \pm 0.24^{a}$ & $0.53 \pm 0.09^{a}$ & $1.70 \pm 0.21^{a}$ & $1.90 \pm 0.21^{a}$ \\
\hline B. cereus & $0.27 \pm 0.03^{b c}$ & $0.63 \pm 0.07^{b}$ & $0.78 \pm 0.04^{b}$ & $0.33 \pm 0.09^{b c d e}$ & $1.47 \pm 0.09^{b}$ & $1.52 \pm 0.07^{\mathrm{bc}}$ & $0.40 \pm 0.04^{\mathrm{ab}}$ & $1.53 \pm 0.07^{\mathrm{ab}}$ & $1.58 \pm 0.02^{a b c}$ \\
\hline P. putida & $0.27 \pm 0.03^{b c}$ & $0.67 \pm 0.07^{b}$ & $0.81 \pm 0.01^{b}$ & $0.37 \pm 0.03^{b c d}$ & $1.67 \pm 0.15^{a b}$ & $1.77 \pm 0.05^{\mathrm{b}}$ & $0.46 \pm 0.03^{a}$ & $1.23 \pm 0.07^{a b c}$ & $1.40 \pm 0.03^{b c d}$ \\
\hline P. libanensis & $0.27 \pm 0.07^{\mathrm{bc}}$ & $0.77 \pm 0,03^{b}$ & $0.88 \pm 0.04^{b}$ & $0.22 \pm 0.02^{d e f}$ & $1.40 \pm 0.17^{b}$ & $1.33 \pm 0.09^{c}$ & $0.38 \pm 0.04^{a b}$ & $1.26 \pm 0.25^{a b c}$ & $1.56 \pm 0.19^{a b c}$ \\
\hline UC & $0.29 \pm 0.07^{b c}$ & $0.41 \pm 0.06^{c}$ & $0.42 \pm 0.04^{c}$ & $0.29 \pm 0.05^{c d e}$ & $0.69 \pm 0.08^{c}$ & $0.79 \pm 0.05^{d}$ & $0.43 \pm 0.03^{a}$ & $0.87 \pm 0.06^{c d}$ & $1.06 \pm 0.12^{d}$ \\
\hline LSD & 0.132 & 0.145 & 0.105 & 0.155 & 0.376 & 0.368 & 0.189 & 0.524 & 0.367 \\
\hline
\end{tabular}

Defense related enzymes viz., peroxidase (PO), polyphenol oxidase (PPO), and phenylalanine ammonia-lyase (PAL) were studied. Sterilized soil was flooded with sporangial suspension of P. myriotylum before transplanting the chili seedlings. Fifteen days old chili seedlings were inoculated with rhizobacterial suspension (10 $\left.{ }^{8} \mathrm{cfu} / \mathrm{mL}\right)$ for $2 \mathrm{~h}$ before transplanting in sick soil containing pots. Root samples were taken 1, 3, and 5 days after transplant. Only P. myriotylum treated pots were considered as negative control (NC) while non-inoculated plants with pathogen were kept us untreated control (UC). Means are an average of three repeats and ( \pm ) indicate the standard error (SE). DAl: days after inoculation.

et al. (2015) reported rhizobacteria belonging to Pseudomonas, Azospirillum, Azotobacter, Klebsiella, Enterobacter, Alcaligenes, Arthobacter, Burkholderia, Bacillus, and Serratia spp. enhance plant growth, and are being used as bio-controls (Labuschagne et al., 2010; El-Sayed et al., 2014; Ganapathy and Natesan, 2018).

In the present study, rhizobacterial isolates were screened for the biocontrol of damping-off and plant growth promotion 

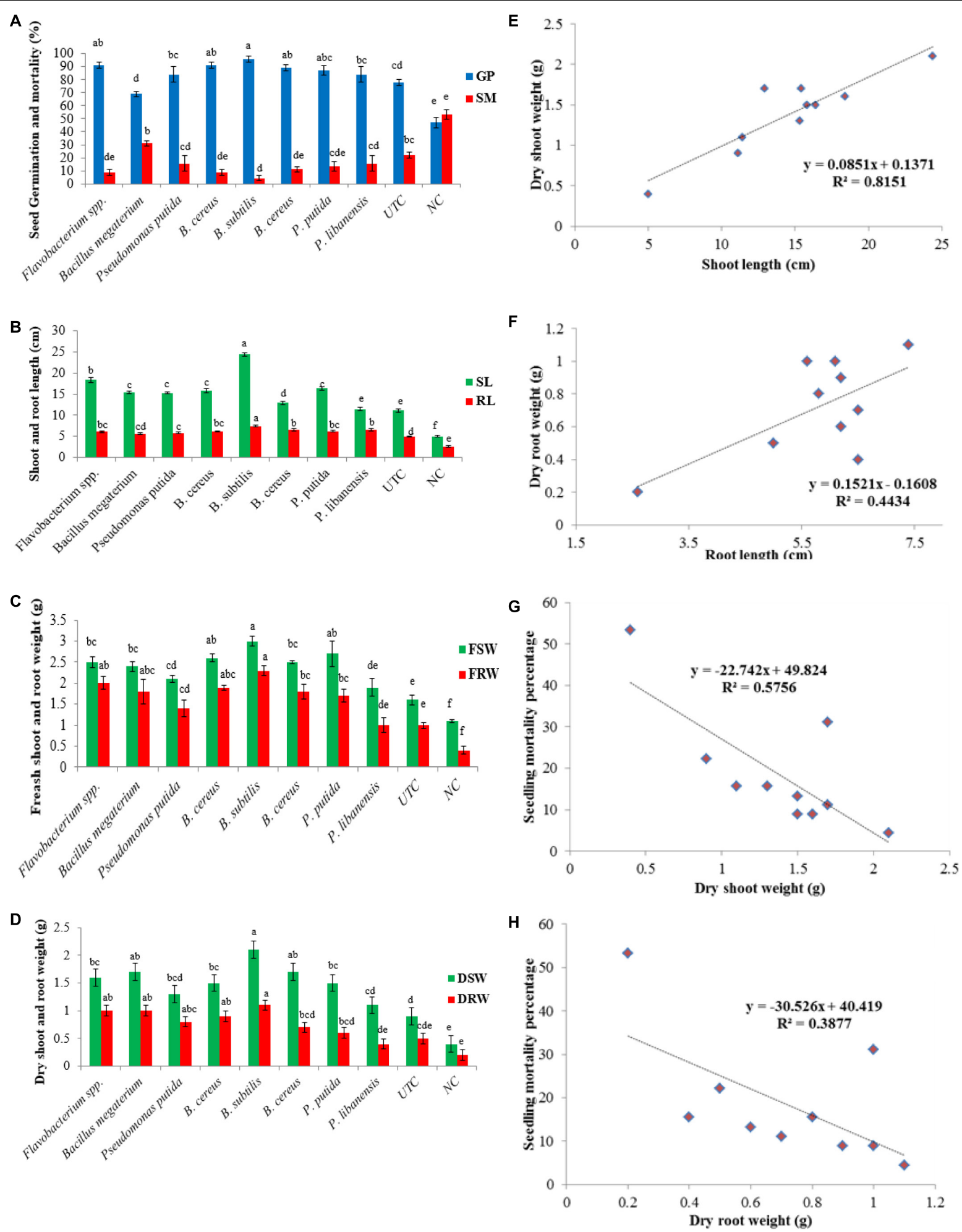

FIGURE 7 | Evaluation of rhizobacteria isolated from chili growing fields for the suppression of Pythium myriotylum and plant growth promotion effects on chili seeds in pot trials. Zoospores of $P$. myriotylum were added into the soil and bacterized chili seedlings were sown in sick soil containing pots in three repeats. Error bars show standard deviations and letters on each bar represent the significant difference among the values at $5 \%$ level of significance. (A) seed germination and seed mortality percentage, (B) shoot and root length, (C) fresh shoot and root weight, (D) dry shoot and root weight, (E) positive correlation between shoot length and dry shoot weight, (F) positive correlation between root length and dry root weight, (G) negative correlation between dry shoot weight and seedling mortality percentage, (H) negative correlation between dry root weight and seedling mortality percentage. 
traits in chili crops. Out of the 110 rhizobacterial isolates, 28 $(22.7 \%)$ showed varied levels of antagonistic potential. Out of these 28 bacterial isolates, eight (28.6\%) isolates Flavobacterium spp., B. megaterium, P. putida, B. cereus, B. subtilis, B. cereus, $P$. putida, and $P$. libanensis showed significantly high antagonistic potential against two highly virulent strains of $P$. myriotylum (PMyr-1 and PMyr-2).

The biological control of Pythium spp. could be due to the antagonistic ability of the rhizobacteria (Clark, 2006; Elazzazy et al., 2012). This antagonistic potential is due to antibiosis, as various antibiotics have been identified and reported in previous studies (Raaijmakers et al., 2002; Nielsen and Sørensen, 2003). The production of antibiotics and lytic enzymes damage the fungal cell membrane and inhibits the zoospores of Oomycetes (Beneduzi et al., 2012).

Bacterial isolates showing the highest antagonistic potential were subjected to biochemical featuring. Out of the eight bacterial isolates, four were gram positive and others were gram negative. Bacterial isolates belonging to Bacillus and Flavobacterium spp. showed negative results for fluorescence emission test, while those belonging to Pseudomonas spp. respond positively. For the potassium hydroxide $(\mathrm{KOH})$ test, bacterial isolates Flavobacterium spp., P. putida and P. libanensis showed positive test results while other isolates were negative for the $\mathrm{KOH}$ test. All the tested bacterial isolates were catalase positive. Many studies have highlighted the catalase production by rhizobacteria (Ali Kamboh et al., 2009; Kumari et al., 2018). Catalase positive bacteria were reported to suppress early blight disease in tomatoes (Senthilraja et al., 2013) and induced resistance against tomato yellow leaf curl virus (Li et al., 2016). Out of the eight bacterial isolates, $B$. cereus and P. libanensis were positive for levan production while $P$. putida and $B$. cereus were fermenting the carbohydrates. With the exception of $P$. libanensis, all the bacterial isolates exhibited positive responses for the oxidase test except B. subtilis. All the tested bacterial isolates showed nitrate reduction, except for Flavobacterium spp. and P. libanensis. All the tested bacterial isolates showed gelatin hydrolysis activity except for Flavobacterium spp. In a similar study, rhizobacterial strains were differentiated based on morphology and biochemical traits (Singh et al., 2019).

The 16S rRNA sequences have been widely used in the classification and identification of Bacteria and Archaea (Goodfellow et al., 2014). The sequence analysis of bacterial isolates indicated that the tested bacterial isolates belonged to three different genera including Flavobacterium spp., Bacillus spp. and Pseudomonas spp. In our studies, 16S rRNA sequencebased neighbor-Joining (N-J) tree indicated that two bacterial isolates ID (MH393211) and 1C2 (MH393210) showed 97 to 98\% sequence identity with Bacillus cereus (accessions MK606105 and MK648339) while JHL-8 (MH393209) showed 99\% sequence homology with B. megaterium (accession MG430236). The sequence of RH-24 (MH393208) had 99\% sequence homology with B. subtilis (accession KY000519) and RH-87 (accession MT421780) showed 99\% identity with Pseudomonas libanensis (DQ095905). Two bacterial isolates 5C (MH371201) and JHL12 (MH371200) had 99\% sequence homology with P. putida (accessions KY982927 and MF276642, respectively). Bacterial isolate 4a2 (accession MT421823) had 99\% identity with the Flavobacterium spp. (accession HM745136). Similar 16S rRNA gene sequence based rhizobacterial characterizations have been reported in other literature (Islam et al., 2016; Kuan et al., 2016; Kumari et al., 2018; Zouaoui et al., 2019).

Bacterial strains were also tested for plant growth promotion traits. All the antagonistic bacterial produced ammonia $\left(\mathrm{NH}_{3}\right)$. Ammonia production is the most common character of PGPR, which indirectly enhances plant growth (Yadav et al., 2010). It accumulates and supplies nitrogen to the host plants and helps in plant growth promotion (Kumar et al., 2016), and it also contributes to antagonism (Howell, 1988). Various researchers have cited the production of ammonia by rhizobacteria (Jayasinghearachchi and Seneviratne, 2004; Triveni et al., 2012; Mazumdar et al., 2019). Furthermore, all the tested bacterial isolates except Flavobacterium spp. were able to hydrolyze starch. The production of HCN by PGPR is independent of their genus. Except for B. cereus and Flavobacterium spp., all the bacterial strains were positive for the HCN production test. Previous researches have documented that the bacterial agents with $\mathrm{HCN}$ producing ability can be used as biocontrol agents (Ramette et al., 2003). It is now believed that HCN production indirectly increases phosphorus availability by chelation and sequestration of metals and indirectly increases the nutrient availability to the rhizobacteria and host plants (Rijavec and Lapanje, 2016), and they are thus used as biofertilizers or as a bio-control to enhance crop production (Agbodjato et al., 2015).

All the bacterial strains were also evaluated for P-solubilization, indole-3-acetic acid (IAA), and siderophore production. Phosphate solubilization is an important plant growth promotion trait of rhizobacteria; in which rhizobacteria produce low molecular weight organic acids which solubilize phosphate thus, lowering the $\mathrm{pH}$ of the soil (Khan et al., 2014) thus, converts the phosphate into available forms that is taken up by the plant roots (Ahmad et al., 2018). In this study, all the bacterial isolates belonging to Flavobacterium, Bacillus, and Pseudomonas spp. showed P-solubilization ability, and the test was not performed for $B$. cereus. Indole-3-acetic acid (IAA) is a vital phytohormone that is involved in root development, elongation, proliferation and facilitates plants to obtain water and nutrients from the soil (Yao et al., 2008). It increases the root surface area and loosens the plant cell walls, which facilitates in getting soil nutrients and supports better plant microbe interaction (Glick, 2012). In our study, all the bacterial isolates produced a considerable amount of IAA (13.4-39.0 $\mathrm{gmL}^{-1}$ ) which were comparable to previously published reports by Islam et al. (2016) and Zahid et al. (2015). The increase in shoot and root length in bacterial inoculated plants may be attributed to their ability to produce IAA. Siderophore production is one of the most influential traits exhibited by plant growth promoting rhizobacteria especially when iron availability is limited (Whipps, 2001) and suppress the phytopathogens by depriving them of available iron (O'sullivan and O'Gara, 1992). All the PGPR tested in this study showed promising siderophore production (17.1-27.7\%) which proves rhizobacterial ability to suppress the growth of target pathogen $P$. myriotylum. Many previous reports have supported the siderophore production potential of 
PGPR and its role in disease suppression (Swadling and Jeffries, 1996; Compant et al., 2005; Sayyed et al., 2019; Ali et al., 2020; Kesharwani and Singh, 2020; Sharf et al., 2021).

Previous studies have proven that heavy metal ions co-regulate genes that confer antibiotic resistance and decrease antibiotic susceptibility (Baker-Austin et al., 2006; Rani et al., 2010). In this study, bacterial isolates were screened for their resistance or susceptibility response against Streptomyces, ampicillin, rifampicin, penicillin G, and vancomycin at five dose levels, and all the tested bacterial strains displayed a varied level of resistance and antibiotic susceptibility response. The study has shown that the tested bacterial isolates have varied levels of tendencies to overcome the antibiotics stress and it might be associated with tolerance against heavy metals present in the soil. Bacterial isolates showing multiple antibiotic resistances have greater chances to establish as inoculum in the soil and any new niche. Metal tolerance and antibiotic resistance have previously been reported in many studies (Thacker et al., 2007; Wani and Irene, 2014).

Treatment of chili seed with selected bacterial strains significantly improved seed germination, plumule and radical length, and vigor index as compared to un-inoculated control. No phytotoxicity and stress on seedling germination had been observed in any treatment. All the antagonists used in this study were non-pathogenic to chili seeds. As these bacterial isolates showed P-solubilization and IAA activity thus, can be used for plant growth promotion (Naureen et al., 2009) and the growth enhancement may be due to the production of IAA. A research study has shown high amylase activity during seed germination in rice and legume inoculated with PGPR (Duarah et al., 2011). A recent study reported that seed treatment with PGPR significantly improved seed germination, plant growth promotion, fresh weight, and improved root formation in greengram and maize crops (Oo et al., 2020).

The level of defense-related enzymes contributes significantly to the mechanism of host plant resistance (Shivakumar et al., 2000). The bacterial inoculated chili plants also displayed a significant increase in defense related enzyme activities. Chili seedlings treated with bacterial isolates exhibited a significant increase in Peroxidase (PO), Polyphenol oxidase (PPO), and Phenylalanine ammonialyas (PAL) activities. PO activity was maximum in the seedlings treated with Flavobacterium spp. followed by B. megaterium and B. subtilis while PPO and PAL activity was recorded significantly high 5 days after inoculation (DAI) in chili roots bacterized with B. subtilis inoculum over un-inoculated (UC) and negative control (NC). Our results are supported by the findings of Benhamou and Paulitz (2000) where cucumber roots inoculation with Pseudomonas corrugate and $P$. aureofaciens suppressed the root and crown rot caused by P. aphanidermatum and PAL accumulation lasted for 16 days while Peroxidase (PO) and Polyphenol oxidase (PPO) activities were enhanced in roots 2 to 5 days after bacterial treatment. It was previously reported that the induction of plant defense related enzymes is related to the plant defense system and induced resistance by PGPR inoculation and colonization (Liang et al., 2011). The accumulation of defense related enzymes after PGPR application has also been reported in cucumber
(Liang et al., 2011), chili (Jayapala et al., 2019), and tomato (Ramamoorthy et al., 2002b). Dukare and Paul (2021) also found that rhizobacterial inoculation conferred resistance to pigeon pea seedlings by inducing and improving the production of defense related enzymes and phenolics.

Many studies have proved that PGPR has great potential to suppress plant pathogens and increase plant growth under greenhouse conditions (Kabdwal et al., 2019). These PGPR induce systemic resistance against a broad spectrum of pathogens due to their root colonization ability (Salem and Abd El-Shafea, 2018). Both Pseudomonas and Bacillus spp. are known for their role in disease suppression against various plant pathogens (Velusamy et al., 2013). In present studies, tested bacterial strains enhanced the chili germination percentage and reduced the seedling mortality percentage by suppressing the P. myriotylum, and a significant increase in plant growth characters was observed in bacterial inoculated treatments over un-treated (UTC) and negative control (NC). Similar results have been reported in other research studies (Egamberdieva, 2011; Almaghrabi et al., 2013; Islam et al., 2016; Torres et al., 2020). Athira and Anith (2020) reported that tomato seed treatment with $R$. radiobacter, $S$. leeuwenhoekii and $P$. indica significantly minimized the disease incidence of bacterial wilt disease of tomato.

The biocontrol of plant pathogens is not very popular in field conditions as the crop is more open to a range of pests that may prevent the development of a specific biological control. Climatic conditions and soil factors also influence the potential of biocontrol agents against disease suppression. Many studies have discussed the low performance of bacterialbased products under open field conditions due to various climatic and soil factors (Ownley et al., 2003), which affect bacterial colonization ability, biological activates, and disease suppressing potential (Landa et al., 2001). Biocontrol is a complex phenomenon involving several mechanisms in disease suppression and understanding these mechanisms would be beneficial for the effective utilization of bacterial biocontrol agents in open fields. Many biocontrol products against dampingoff disease are available worldwide (Lamichhane et al., 2017) but not a single locally prepared product is available and registered in Pakistan. Bio-products imported from other countries failed to perfume due to the nature of different soils and climatic conditions. Taking this into account, this study aimed to screen out the native bacterial antagonists with high disease suppressive and plant growth promotion abilities. To our knowledge, the antagonistic potential of native PGPR was first reported in Pakistan. However, a series of further experiments are required to test the efficacy of these bacterial isolates at different dose levels and formulations with different soil types and climatic conditions. Finally, field trials will help to develop the bacterial based bioproduct, its registration, and commercialization.

\section{CONCLUSION}

Plant disease suppression and growth promotion are considerable aspects in achieving good quality produce. 
Chili pepper is cultivated as an important vegetable crop across the world, and its production is greatly reduced by the damping-off disease caused by Pythium myriotylum. In response, this study screened rhizobacterial isolates in vitro which showed greater potential to suppress $P$. myriotylum inoculum, and significantly improved the seedling germination and vigor index without posing any phytotoxicity and pathogenic impact on young seedlings. These bacterial isolates showed P-solubilization, indole-3-acetic acid, and siderophores production ability and produced varying levels of susceptibility and tolerance response against antibiotics. The application of bacterial isolates increased the accumulation and activities of defense related enzymes (PO, PPO, and PAL) in chili roots under pathogen pressure. These PGPR, which have multiple disease suppressive and PGP traits, significantly reduced the seedling mortality and improved the seedling germination and other PGP traits in pot trials. However, more detailed study is required, examining dose calibration, and field performance testing of these PGPR is required to ensure the safe application of these bacteria as biocontrol agents.

\section{DATA AVAILABILITY STATEMENT}

The data supporting the findings of this study are available within the article.

\section{REFERENCES}

Abbasi, M. K., Sharif, S., Kazmi, M., Sultan, T., and Aslam, M. (2011). Isolation of plant growth promoting rhizobacteria from wheat rhizosphere and their effect on improving growth, yield and nutrient uptake of plants. Plant Biosyst. 145, 159-168. doi: 10.1080/11263504.2010.542318

Achnine, L., Blancaflor, E. B., Rasmussen, S., and Dixon, R. A. (2004). Colocalization of L-phenylalanine ammonia-lyase and cinnamate 4hydroxylase for metabolic channeling in phenylpropanoid biosynthesis. Plant Cell 16, 3098-3109. doi: 10.1105/tpc.104.024406

Agbodjato, N. A., Noumavo, P. A., Baba-Moussa, F., Salami, H. A., Sina, H., Sèzan, A., et al. (2015). Characterization of potential plant growth promoting rhizobacteria isolated from maize (Zea mays L.) in central and Northern Benin (West Africa). Appl. Environ. Soil Sci. 2015, 1-9. doi: 10.1155/2015/901656

Ahmad, M., Ahmad, I., Hilger, T. H., Nadeem, S. M., Akhtar, M. F., Jamil, M., et al. (2018). Preliminary study on phosphate solubilizing Bacillus subtilis strain Q3 and Paenibacillus sp. strain Q6 for improving cotton growth under alkaline conditions. PeerJ 6:e5122. doi: 10.7717/peerj.5122

Al-Hussini, H. S., Al-Rawahi, A. Y., Al-Marhoon, A. A., Al-Abri, S. A., AlMahmooli, I. H., Al-Sadi, A. M., et al. (2019). Biological control of damping-off of tomato caused by Pythium aphanidermatum by using native antagonistic rhizobacteria isolated from Omani soil. J. Plant Pathol. 101, 315-322. doi: 10.1007/s42161-018-0184-x

Ali, S., Hameed, S., Shahid, M., Iqbal, M., Lazarovits, G., and Imran, A. (2020). Functional characterization of potential PGPR exhibiting broad-spectrum antifungal activity. Microbiol. Res. 232:126389. doi: 10.1016/j.micres.2019. 126389

Ali Kamboh, A., Rajput, N., Rajput, I. R., Khaskheli, M., and Khaskheli, G. B. (2009). Biochemical properties of bacterial contaminants isolated from livestock vaccines. Pakistan J. Nutr. 8, 578-581. doi: 10.3923/pjn.2009.578.581

Almaghrabi, O. A., Massoud, S. I., and Abdelmoneim, T. S. (2013). Influence of inoculation with plant growth promoting rhizobacteria (PGPR) on tomato

\section{AUTHOR CONTRIBUTIONS}

SH designed research, conducted experiments, and wrote manuscript. AG helped in conducting research experiments, data analysis, manuscript write up, and proofreading. ZR helped in data analysis and proofreading. RA helped in data analysis and interpreting the results. MISH and NF helped in research work and data collection. MI conceived the idea and supervised the research work. All authors contributed to the article and approved the submitted version.

\section{FUNDING}

This study received financial assistance from the Higher Education Commission (HEC) and Punjab Agriculture Research Board (PARB), Pakistan.

\section{ACKNOWLEDGMENTS}

Financial support received from the Higher Education Commission (HEC) and Punjab Agriculture Research Board (PARB), Pakistan for carrying out this research work is gratefully acknowledged. We also acknowledge Prof. Youfu Frank Zhao, Department of Crop Sciences, the University of Illinois at Urbana-Champaign for providing bench space in his laboratory and helping in various research activities.

plant growth and nematode reproduction under greenhouse conditions. Saudi J. Biol. Sci. 20, 57-61. doi: 10.1016/j.sjbs.2012.10.004

Anand, T., Chandrasekaran, A., Kuttalam, S., Raguchander, T., Prakasam, V., and Samiyappan, R. (2007). Association of some plant defense enzyme activities with systemic resistance to early leaf blight and leaf spot induced in tomato plants by azoxystrobin and Pseudomonas fluorescens. J. Plant Interact. 2, 233-244. doi: 10.1080/17429140701708985

Aneja, K. (2001). Experiments in Microbiology, Plant Pathology, Tissue Culture and Mushroom Production Technology. Chennai: New Age International Limited.

Athira, S., and Anith, K. (2020). Plant growth promotion and suppression of bacterial wilt incidence in tomato by rhizobacteria, bacterial endophytes and the root endophytic fungus Piriformospora indica. Indian Phytopathol. 73, 629-642. doi: 10.1007/s42360-020-00283-2

Baker-Austin, C., Wright, M. S., Stepanauskas, R., and McArthur, J. V. (2006). Co-selection of antibiotic and metal resistance. Trends Microbiol. 14, 176-182. doi: 10.1016/j.tim.2006.02.006

Begum, M., Rai, V. R., and Lokesh, S. (2012). Effect of plant growth promoting rhizobacteria on seed borne fungal pathogens in okra. Indian Phytopathol. 56, 156-158.

Beneduzi, A., Ambrosini, A., and Passaglia, L. M. (2012). Plant growth-promoting rhizobacteria (PGPR): their potential as antagonists and biocontrol agents. Genet. Mol. Biol. 35, 1044-1051. doi: 10.1590/s1415-47572012000600020

Benhamou, N., and Paulitz, T. C. (2000). Defense enzymes induced in cucumber roots by treatment with plant growth-promoting rhizobacteria (PGPR) and Pythium aphanidermatum. Physiol. Mol. Plant Pathol. 56, 13-23. doi: 10.1006/ pmpp.1999.0243

Ben-Yephet, Y., and Nelson, E. B. (1999). Differential suppression of dampingoff caused by Pythium aphanidermatum, P. irregulare, and P. myriotylum in composts at different temperatures. Plant Dis. 83, 356-360. doi: 10.1094/pdis. 1999.83.4.356

Bourguet, D., and Guillemaud, T. (2016). The Hidden and External Costs of Pesticide Use, Sustainable Agriculture Reviews. Berlin: Springer, 35-120. 
Bressa, G., Sisti, E., and Cima, F. (1997). PCBs and organochlorinated pesticides in eel (Anguilla anguilla L.) from the Po Delta. Mar. Chem. 58, 261-266. doi: 10.1016/s0304-4203(97)00053-4

Cappuccino, J. G., and Sherman, N. (2005). Microbiology: a Laboratory Manual. San Francisco, CA: Pearson/Benjamin Cummings.

Cazorla, F. M., Romero, D., Pérez-García, A., Lugtenberg, B. J. J., Vicente, A. D., and Bloemberg, G. (2007). Isolation and characterization of antagonistic Bacillus subtilis strains from the avocado rhizoplane displaying biocontrol activity. J. Appl. Microbiol. 103, 1950-1959. doi: 10.1111/j.1365-2672.2007. 03433.x

Chen, L., Dodd, I. C., Theobald, J. C., Belimov, A. A., and Davies, W. J. (2013). The rhizobacterium Variovorax paradoxus 5C-2, containing ACC deaminase, promotes growth and development of Arabidopsis thaliana via an ethylenedependent pathway. J. Exp. Bot. 64, 1565-1573. doi: 10.1093/jxb/ert031

Chen, X., Koumoutsi, A., Scholz, R., Schneider, K., Vater, J., Süssmuth, R., et al. (2009). Genome analysis of Bacillus amyloliquefaciens FZB42 reveals its potential for biocontrol of plant pathogens. J. Biotechnol. 140, 27-37. doi: 10.1016/j.jbiotec.2008.10.011

Clark, M. M. (2006). Biological Control Methods for Damping-off of Tomato Seedlings Caused by Pythium myriotylum. Master's Thesis. Knoxville, TN: University of Tennessee.

Compant, S., Duffy, B., Nowak, J., Clément, C., and Barka, E. A. (2005). Use of plant growth-promoting bacteria for biocontrol of plant diseases: principles, mechanisms of action, and future prospects. Appl. Environ. Microbiol. 71, 4951-4959. doi: 10.1128/aem.71.9.4951-4959.2005

Compant, S., Van Der Heijden, M. G., and Sessitsch, A. (2010). Climate change effects on beneficial plant-microorganism interactions. FEMS Microbiol. Ecol. 73, 197-214.

Dorrance, A., Robertson, A., Cianzo, S., Giesler, L. J., Grau, C., Draper, M., et al. (2009). Integrated management strategies for Phytophthora sojae combining host resistance and seed treatments. Plant Dis. 93, 875-882. doi: 10.1094/pdis93-9-0875

Drechsler, C. (1943). Two species of Pythium occurring in southern States. Phytopathology 33, 261-299.

du Toit, L. J. (2004). Management of diseases in seed crops. Encycl. Plant Crop Sci. 675-677.

Duarah, I., Deka, M., Saikia, N., and Deka Boruah, H. P. (2011). Phosphate solubilizers enhance NPK fertilizer use efficiency in rice and legume cultivation. 3 Biotech 1, 227-238. doi: 10.1007/s13205-011-0028-2

Dukare, A., and Paul, S. (2021). Biological control of Fusarium wilt and growth promotion in pigeon pea (Cajanus cajan) by antagonistic rhizobacteria, displaying multiple modes of pathogen inhibition. Rhizosphere 17:100278. doi: 10.1016/j.rhisph.2020.100278

Egamberdieva, D. (2011). Survival of Pseudomonas extremorientalis TSAU20 and $P$. chlororaphis TSAU13 in the rhizosphere of common bean (Phaseolus vulgaris) under saline conditions. Plant Soil Environ. 57, 122-127. doi: 10. 17221/316/2010-pse

Elazzazy, A. M., Almaghrabi, O. A., Moussa, T. A., and Abdelmoneim, T. S. (2012). Evaluation of some plant growth promoting rhizobacteria (pgpr) to control Pythium aphanidermatum in cucumber plants. Life Sci. J. 9, 3147-3153.

El-Sayed, W. S., Akhkha, A., El-Naggar, M. Y., and Elbadry, M. (2014). In vitro antagonistic activity, plant growth promoting traits and phylogenetic affiliation of rhizobacteria associated with wild plants grown in arid soil. Front. Microbiol. 5:651.

El-Tarabily, K., Nassar, A., Hardy, G. S. J., and Sivasithamparam, K. (2009). Plant growth promotion and biological control of Pythium aphanidermatum, a pathogen of cucumber, by endophytic actinomycetes. J. Appl. Microbiol. 106, 13-26. doi: 10.1111/j.1365-2672.2008.03926.x

Erwin, D. C., and Ribeiro, O. K. (1996). Phytophthora Diseases Worldwide. Saint Paul, MN: American Phytopathological Society (APS Press).

Etesami, H., Alikhani, H. A., and Hosseini, H. M. (2015). Indole-3-acetic acid (IAA) production trait, a useful screening to select endophytic and rhizosphere competent bacteria for rice growth promoting agents. MethodsX 2, 72-78. doi: 10.1016/j.mex.2015.02.008

Ganapathy, A., and Natesan, S. (2018). Metabolic Potential and Biotechnological Importance of Plant Associated Endophytic Actinobacteria, New and Future Developments in Microbial Biotechnology and Bioengineering. Amsterdam: Elsevier, 207-224.
Glick, B. R. (2012). Plant growth-promoting bacteria: mechanisms and applications. Scientifica 2012, 1-15. doi: 10.1142/9781848160521_0001

Gómez-Lama Cabanás, C., Schilirò, E., Valverde-Corredor, A., and MercadoBlanco, J. (2014). The biocontrol endophytic bacterium Pseudomonas fluorescens PICF7 induces systemic defense responses in aerial tissues upon colonization of olive roots. Front. Microbiol. 5:427.

Goodfellow, M., Sutcliffe, I., and Chun, J. (2014). Preface, Methods in Microbiology. Amsterdam: Elsevier, xix.

Gordon, S. A., and Weber, R. P. (1951). Colorimetric estimation of indoleacetic acid. Plant Physiol. 26:192. doi: 10.1104/pp.26.1.192

Goudjal, Y., Toumatia, O., Yekkour, A., Sabaou, N., Mathieu, F., and Zitouni, A. (2014). Biocontrol of Rhizoctonia solani damping-off and promotion of tomato plant growth by endophytic actinomycetes isolated from native plants of Algerian Sahara. Microbiol. Res. 169, 59-65. doi: 10.1016/j.micres.2013.06.014

Gupta, G., Parihar, S. S., Ahirwar, N. K., Snehi, S. K., and Singh, V. (2015). Plant growth promoting rhizobacteria (PGPR): current and future prospects for development of sustainable agriculture. J. Microb. Biochem. Technol. 7, 096-102.

Habib, S., Kausar, H., Saud, H., Ismail, M., and Othman, R. (2016). Molecular characterization of stress tolerant plant growth promoting rhizobacteria (PGPR) for growth enhancement of rice. Int. J. Agric. Biol. 18, 184-191. doi: 10.17957/ijab/15.0094

Hammerschmidt, R., Nuckles, E., and Kuæ, J. (1982). Association of enhanced peroxidase activity with induced systemic resistance of cucumber to Colletotrichum lagenarium. Physiol. Plant Pathol. 20, 73-82. doi: 10.1016/00484059(82)90025-x

Hayward, A. (1960). A method for characterizing Pseudomonas solanacearum. Nature 186, 405-406. doi: 10.1038/186405a0

Horst, R. K. (2013). Westcott's Plant Disease Handbook. Berlin: Springer Science \& Business Media.

Howell, C. R. (1988). Production of Ammonia byEnterobacter cloacaeand its possible role in the biological control of pythium preemergence dampingoff by the Bacterium. Phytopathology 78, 1075. doi: 10.1094/phyto-781075

Hugh, R., and Leifson, E. (1953). The taxonomic significance of fermentative versus oxidative metabolism of carbohydrates by various gram negative bacteria. J. Bacteriol. 66:24. doi: 10.1128/jb.66.1.24-26.1953

Hussain, S., Siddique, T., Saleem, M., Arshad, M., and Khalid, A. (2009). Impact of pesticides on soil microbial diversity, enzymes, and biochemical reactions. $A d v$. Agron. 102, 159-200. doi: 10.1016/s0065-2113(09)01005-0

Hyder, S., Inam-ul-Haq, M., Ashfaq, M., Ahmad, A., Gondal, A., and Iqbal, M. (2018). First report of Pythium myriotylum D., causing damping off and root rot in chili pepper (Capsicum annum L.) from Punjab, Pakistan. Plant Dis. 102, 687-687. doi: 10.1094/pdis-06-17-0788-pdn

Islam, S., Akanda, A. M., Prova, A., Islam, M. T., and Hossain, M. M. (2016). Isolation and identification of plant growth promoting rhizobacteria from cucumber rhizosphere and their effect on plant growth promotion and disease suppression. Front. Microbiol. 6:1360. doi: 10.3389/fmicb.2015.01360

Jayapala, N., Mallikarjunaiah, N. H., Puttaswamy, H., Gavirangappa, H., and Ramachandrappa, N. S. (2019). Rhizobacteria Bacillus spp. induce resistance against anthracnose disease in chili (Capsicum annuum L.) through activating host defense response. Egypt. J. Biol. Pest Control 29:45.

Jayasinghearachchi, H. S., and Seneviratne, G. (2004). A bradyrhizobial-Penicillium spp. biofilm with nitrogenase activity improves N2 fixing symbiosis of soybean. Biol. Fertility Soils 40, 432-434. doi: 10.1007/s00374-004-0796-5

Jeffers, S., and Martin, S. (1986). Comparison of two media selective for Phytophthora and Pythium species. Plant Dis. 70, 1038-1043.

Jockusch, H. (1966). The role of host genes, temperature and polyphenoloxidase in the necrotization of TMV infected tobacco tissue. J. Phytopathol. 55, 185-192. doi: 10.1111/j.1439-0434.1966.tb02222.x

Joseph, B., Ranjan Patra, R., and Lawrence, R. (2012). Characterization of plant growth promoting rhizobacteria associated with chickpea (Cicer arietinum L.). Int. J. Plant Prod. 1, 141-152.

Kabdwal, B. C., Sharma, R., Tewari, R., Tewari, A. K., Singh, R. P., and Dandona, J. K. (2019). Field efficacy of different combinations of Trichoderma harzianum, Pseudomonas fluorescens, and arbuscular mycorrhiza fungus against the major diseases of tomato in Uttarakhand (India). Egypt. J. Biol. Pest Control 29:1. doi: 10.1007/978-3-319-23534-9_1 
Kageyama, K., and Ui, T. (1983). Host range and distribution of Pythium myriotylum and unidentified Pythium sp. contributed to the monoculture injury of bean and soybean plants. Japanese J. Phytopathol. 49, 148-152.

Kandel, Y. R., Wise, K. A., Bradley, C. A., Chilvers, M. I., Tenuta, A. U., and Mueller, D. S. (2016). Fungicide and cultivar effects on sudden death syndrome and yield of soybean. Plant Dis. 100, 1339-1350. doi: 10.1094/pdis-11-15-1263-re

Kandeler, E., Mosier, A. R., Morgan, J. A., Milchunas, D. G., King, J. Y., Rudolph, S., et al. (2006). Response of soil microbial biomass and enzyme activities to the transient elevation of carbon dioxide in a semi-arid grassland. Soil Biol. Biochem. 38, 2448-2460. doi: 10.1016/j.soilbio.2006.02.021

Kenawy, A., Dailin, D. J., Abo-Zaid, G. A., Malek, R. A., Ambehabati, K. K., Zakaria, K. H. N., et al. (2019). Biosynthesis of Antibiotics by PGPR and Their Roles in Biocontrol of Plant Diseases, Plant Growth Promoting Rhizobacteria for Sustainable Stress Management. Berlin: Springer, 1-35.

Kesharwani, A. K., and Singh, R. P. (2020). Characterization of plant growthpromoting rhizobacteria isolated from chilli rhizosphere of Southern Plateau and hills region. Int. J. Curr. Microbiol. App. Sci. 9, 3473-3483. doi: 10.20546/ ijcmas.2020.908.402

Khan, M. S., Zaidi, A., and Ahmad, E. (2014). Mechanism of Phosphate Solubilization and Physiological Functions of Phosphate-Solubilizing Microorganisms, Phosphate Solubilizing Microorganisms. Berlin: Springer International Publishing, 31-62.

Kirsop, B., and Doyle, A. (1991). Maintenance of Microorganisms on Cultured Cells. A Manual of Food Practice. London: Academic Press.

Kloepper, J. W., Lifshitz, R., and Zablotowicz, R. M. (1989). Free-living bacterial inocula for enhancing crop productivity. Trends Biotechnol. 7, 39-44. doi: 10.1016/0167-7799(89)90057-7

Kuan, K. B., Othman, R., Abdul Rahim, K., and Shamsuddin, Z. H. (2016). Plant growth-promoting rhizobacteria inoculation to enhance vegetative growth, nitrogen fixation and nitrogen remobilisation of maize under greenhouse conditions. PLoS One 11:e0152478. doi: 10.1371/journal.pone.015 2478

Kumar, M., Kaur, A., Pachouri, C. U., and Singh, J. (2015). Growth promoting characteristics of rhizobacteria and AM Fungi for biomass amelioration of Zea mays. Arch. Biol. Sci. 67, 877-887. doi: 10.2298/abs141029047k

Kumar, M., Mishra, S., Dixit, V., Kumar, M., Agarwal, L., Chauhan, P. S., et al. (2016). Synergistic effect of Pseudomonas putida and Bacillus amyloliquefaciens ameliorates drought stress in chickpea (Cicer arietinum L.). Plant Signal. Behav. 11:e1071004. doi: 10.1080/15592324.2015.1071004

Kumar, S., Stecher, G., Li, M., Knyaz, C., and Tamura, K. (2018). MEGA X: molecular evolutionary genetics analysis across computing platforms. Mol. Biol. Evol. 35, 1547-1549. doi: 10.1093/molbev/msy096

Kumari, P., Meena, M., and Upadhyay, R. S. (2018). Characterization of plant growth promoting rhizobacteria (PGPR) isolated from the rhizosphere of Vigna radiata (mung bean). Biocatal. Agric. Biotechnol. 16, 155-162. doi: 10.1016/j. bcab.2018.07.029

Labuschagne, N., Pretorius, T., and Idris, A. (2010). Plant Growth Promoting Rhizobacteria as Biocontrol Agents Against Soil-borne Plant Diseases, Plant Growth and Health Promoting Bacteria. Berlin: Springer, 211-230.

Lamichhane, J. R., Dürr, C., Schwanck, A. A., Robin, M.-H., Sarthou, J.-P., Cellier, V., et al. (2017). Integrated management of damping-off diseases. A review. Agron. Sustain. Dev. 37:10.

Landa, B. B., Navas-Cortés, J. A., Hervás, A., and Jiménez-Díaz, R. M. (2001). Influence of temperature and inoculum density of Fusarium oxysporumf. sp.cicerison suppression of Fusarium wilt of chickpea by rhizosphere bacteria. Phytopathology 91, 807-816. doi: 10.1094/phyto.2001.91.8.807

Lelliott, R. A., and Stead, D. E. (1987). Methods for the Diagnosis of Bacterial Diseases of Plants. Hoboken, NJ: Blackwell Scientific Publications.

Li, H., Ding, X., Wang, C., Ke, H., Wu, Z., Wang, Y., et al. (2016). Control of Tomato yellow leaf curl virus disease by Enterobacter asburiaeBQ9 as a result of priming plant resistance in tomatoes. Turkish J. Biol. 40, 150-159. doi: 10.3906/biy-1502-12

Liang, J.-G., Tao, R.-X., Hao, Z.-N., Wang, L., and Zhang, X. (2011). Induction of resistance in cucumber against seedling damping-off by plant growthpromoting rhizobacteria (PGPR) Bacillus megaterium strain L8. Afr. J. Biotechnol. 10, 6920-6927.
Lim, J.-H. L. (2010). Biocontrol of phytophthora blight of red pepper caused by Phytophthora capsici using Bacillus subtilis AH18 and B. licheniformis K11 formulations. J. Korean Soc. Appl. Biol. Chem. 53, 766-773. doi: 10.3839/jksabc. 2010.116

Liu, C., Chen, X., Liu, T., Lian, B., Gu, Y., Caer, V., et al. (2007). Study of the antifungal activity of Acinetobacter baumannii LCH001 in vitro and identification of its antifungal components. Appl. Microbiol. Biotechnol. 76, 459-466. doi: 10.1007/s00253-007-1010-0

Lorck, H. (1948). Production of hydrocyanic acid by bacteria. Physiol. Plant. 1, 142-146. doi: 10.1111/j.1399-3054.1948.tb07118.x

Lugtenberg, B., and Kamilova, F. (2009). Plant-growth-promoting rhizobacteria. Annu. Rev. Microbiol. 63, 541-556.

Mancini, V., and Romanazzi, G. (2014). Seed treatments to control seedborne fungal pathogens of vegetable crops. Pest Manage. Sci. 70, 860-868. doi: 10. $1002 /$ ps.3693

Marten, P., Smalla, K., and Berg, G. (2000). Genotypic and phenotypic differentiation of an antifungal biocontrol strain belonging to Bacillus subtilis. J. Appl. Microbiol. 89, 463-471. doi: 10.1046/j.1365-2672.2000.01136.x

Mayer, A., Harel, E., and Ben-Shaul, R. (1966). Assay of catechol oxidase-a critical comparison of methods. Phytochemistry 5, 783-789. doi: 10.1016/ s0031-9422(00)83660-2

Mazumdar, D., Saha, S. P., and Ghosh, S. (2019). Isolation, screening and application of a potent PGPR for enhancing growth of Chickpea as affected by nitrogen level. Int. J. Veg. Sci. 26, 1-18.

Meghvansi, M., Siddiqui, S., Khan, M. H., Gupta, V., Vairale, M., Gogoi, H., et al. (2010). Naga chilli: a potential source of capsaicinoids with broad-spectrum ethnopharmacological applications. J. Ethnopharmacol. 132, 1-14. doi: 10. 1016/j.jep.2010.08.034

Miljaković, D., Marinković, J., and Balešević-Tubić, S. (2020). The significance of Bacillus spp. in disease suppression and growth promotion of field and vegetable crops. Microorganisms 8, 1037. doi: 10.3390/microorganisms8071037

Murphy, J., and Riley, J. P. (1962). A modified single solution method for the determination of phosphate in natural waters. Anal. Chim. Acta 27, 31-36. doi: 10.1016/s0003-2670(00)88444-5

Naureen, Z., Price, A. H., Hafeez, F. Y., and Roberts, M. R. (2009). Identification of rice blast disease-suppressing bacterial strains from the rhizosphere of rice grown in Pakistan. Crop Protection 28, 1052-1060. doi: 10.1016/j.cropro.2009. 08.007

Nielsen, T. H., and Sørensen, J. (2003). Production of Cyclic Lipopeptides by Pseudomonas fluorescens strains in bulk soil and in the sugar beet rhizosphere. Appl. Environ. Microbiol. 69, 861-868. doi: 10.1128/aem.69.2.861-868.2003

Okada, T. (2003). A new causal agent of Pythium damping-off of adzuki bean. Jpn J. Phytopathol. 69, 75.

Onstad, D. W. (2013). Insect Resistance Management: Biology, Economics, and Prediction. Cambridge, MA: Academic Press.

Oo, K. T., Win, T. T., Khai, A. A., and Fu, P. (2020). Isolation, screening and molecular characterization of multifunctional plant growth promoting rhizobacteria for a sustainable agriculture. Am. J. Plant Sci. 11, 773-792. doi: 10.4236/ajps.2020.116055

O'sullivan, D. J., and O'Gara, F. (1992). Traits of fluorescent Pseudomonas spp. involved in suppression of plant root pathogens. Microbiol. Mol. Biol. Rev. 56, 662-676. doi: 10.1128/mmbr.56.4.662-676.1992

Ouyang, W., Cai, G., Huang, W., and Hao, F. (2016). Temporal-spatial loss of diffuse pesticide and potential risks for water quality in China. Sci. Total Environ. 541, 551-558. doi: 10.1016/j.scitotenv.2015. 09.120

Ownley, B. H., Duffy, B. K., and Weller, D. M. (2003). Identification and manipulation of soil properties to improve the biological control performance of phenazine-producing Pseudomonas fluorescens. Appl. Environ. Microbiol. 69, 3333-3343. doi: 10.1128/aem.69.6.3333-3343.2003

Panhwar, Q. A., Naher, U. A., Jusop, S., Othman, R., Latif, M. A., and Ismail, M. R. (2014). Biochemical and molecular characterization of potential phosphate-solubilizing bacteria in acid sulfate soils and their beneficial effects on rice growth. PLoS One 9:e97241. doi: 10.1371/journal.pone.009 7241

Payne, S. M. (1994). Detection, isolation, and characterization of siderophores. Methods Enzymol. 235, 329-344. doi: 10.1016/0076-6879(94)35151-1 
Postma, J., Montanari, M., and van den Boogert, P. H. (2003). Microbial enrichment to enhance the disease suppressive activity of compost. Eur. J. Soil Biol. 39, 157-163. doi: 10.1016/s1164-5563(03)00031-1

Raaijmakers, J. M., Vlami, M., and de Souza, J. T. (2002). Antibiotic production by bacterial biocontrol agents. Antonie Van Leeuwenhoek 81, 537-547.

Rabindran, R., and Vidhyasekaran, P. (1996). Development of a formulation of Pseudomonas fluorescens PfALR2 for management of rice sheath blight. Crop Prot. 15, 715-721. doi: 10.1016/s0261-2194(96)00045-2

Rahimian, M., and Banihashemi, Z. (1979). A method for obtaining zoospores of Pythium aphanidermatum and their use in determining cucurbit seedling resistance to damping-off. Plant Dis. Reporter 63, 658-661.

Ramamoorthy, V., Raguchander, T., and Samiyappan, R. (2002a). Enhancing resistance of tomato and hot pepper to Pythium diseases by seed treatment with fluorescent pseudomonads. Eur. J. Plant Pathol. 108, 429-441.

Ramamoorthy, V., Raguchander, T., and Samiyappan, R. (2002b). Induction of defense-related proteins in tomato roots treated with Pseudomonas fluorescens Pf1 and Fusarium oxysporum f. sp. lycopersici. Plant Soil 239, 55-68.

Ramette, A., Frapolli, M., Défago, G., and Moënne-Loccoz, Y. (2003). Phylogeny of HCN synthase-EncodinghcnBCGenes in biocontrol fluorescent pseudomonads and its relationship with host plant species and HCN synthesis ability. Mol. Plant Microbe Interact. 16, 525-535. doi: 10.1094/mpmi.2003.16.6.525

Rani, M. J., Hemambika, B., Hemapriya, J., and Kannan, V. R. (2010). Comparative assessment of heavy metal removal by immobilized and dead bacterial cells: a biosorption approach. Afr. J. Environ. Sci. Technol. 4, 23-30.

Rijavec, T., and Lapanje, A. (2016). Hydrogen cyanide in the rhizosphere: not suppressing plant pathogens, but rather regulating availability of phosphate. Front. Microbiol. 7:1785.

Robideau, G. P., de Cock, A. W., Coffey, M. D., Voglmayr, H., Brouwer, H., Bala, K., et al. (2011). DNA barcoding of oomycetes with cytochrome c oxidase subunit I and internal transcribed spacer. Mol. Ecol. Resour. 11, 1002-1011. doi: 10.1111/j.1755-0998.2011.03041.x

Rothrock, C., Winters, S., Miller, P., Gbur, E., Verhalen, L., Greenhagen, B., et al. (2012). Importance of fungicide seed treatment and environment on seedling diseases of cotton. Plant Dis. 96, 1805-1817.

Ryan, R. P., Germaine, K., Franks, A., Ryan, D. J., and Dowling, D. N. (2008). Bacterial endophytes: recent developments and applications. FEMS Microbiol. Lett. 278, 1-9. doi: 10.1111/j.1574-6968.2007.00918.x

Salem, E. A., and Abd El-Shafea, Y. M. (2018). Biological control of potato soft rot caused by Erwinia carotovora subsp. carotovora. Egypt. J. Biol. Pest Control 28:94.

Sayyed, R. Z., Seifi, S., Patel, P. R., Shaikh, S. S., Jadhav, H. P., and Enshasy, H. E. (2019). Siderophore production in groundnut rhizosphere isolate, Achromobacter sp. RZS2 influenced by physicochemical factors and metal ions. Environ. Sustain. 2, 117-124. doi: 10.1007/s42398-019-00070-4

Schwyn, B., and Neilands, J. (1987). Universal chemical assay for the detection and determination of siderophores. Anal. Biochem. 160, 47-56. doi: 10.1016/00032697(87)90612-9

Seleim, M., Saead, F., Abd-El-Moneem, K., and Abo-Elyousr, K. (2011). Biological control of bacterial wilt of tomato by plant growth promoting rhizobacteria. Plant Pathol. J. 10, 146-153. doi: 10.3923/ppj.2011.146.153

Senthilraja, G., Anand, T., Kennedy, J. S., Raguchander, T., and Samiyappan, R. (2013). Plant growth promoting rhizobacteria (PGPR) and entomopathogenic fungus bioformulation enhance the expression of defense enzymes and pathogenesis-related proteins in groundnut plants against leafminer insect and collar rot pathogen. Physiol. Mol. Plant Pathol. 82, 10-19. doi: 10.1016/j.pmpp. 2012.12.002

Sharf, W., Javaid, A., Shoaib, A., and Khan, I. H. (2021). Induction of resistance in chili against Sclerotium rolfsii by plant-growth-promoting rhizobacteria and Anagallis arvensis. Egypt. J. Biol. Pest Control 31, 1-11.

Shivakumar, P., Vasanthi, N., Shetty, H., and Smedegaard-Petersen, V. (2000). Ribonucleases in the seedlings of pearl millet and their involvement in resistance against downy mildew disease. Eur. J. Plant Pathol. 106, $825-836$.

Sid, A., Ezziyyani, M., Egea-Gilabert, C., and Candela, M. (2003). Selecting bacterial strains for use in the biocontrol of diseases caused by Phytophthora capsici and Alternaria alternata in sweet pepper plants. Biol. Plant. 47, 569-574. doi: 10.1023/b:biop.0000041063.38176.4a
Singh, R., Kumar, A., Singh, M., and Pandey, K. D. (2019). Isolation and Characterization of Plant Growth Promoting Rhizobacteria From Momordica Charantia L, PGPR Amelioration in Sustainable Agriculture. Amsterdam: Elsevier, 217-238.

Singh, R. K., Singh, N. P., Shahi, J. P., and Jaiswal, H. K. (2013). Multiple antibiotic resistant plant growth promoting rhizobacteria (PGPR) expressed significant increase in growth of maize plants. Int. J. Pharm. Biol. Res. 3, 240-248.

Smith, R. S. Jr. (1975). Charcoal Root Disease. Forest Nursery Diseases in the United States. GW Peterson and RS Smith Jr., Tech. Coordinators, Vol. 470. Washington. DC: U.S.D.A. Forest Serv, 11-13.

Souza, R. D., Ambrosini, A., and Passaglia, L. M. (2015). Plant growth-promoting bacteria as inoculants in agricultural soils. Genet. Mol. Biol. 38, 401-419. doi: 10.1590/s1415-475738420150053

Suwitchayanon, P., Chaipon, S., Chaichom, S., and Kunasakdakul, K. (2018). Potentials of Streptomyces rochei ERY1 as an endophytic actinobacterium inhibiting damping-off pathogenic fungi and growth promoting of cabbage seedling. Chiang Mai J. Sci. 45, 692-700.

Swadling, I. R., and Jeffries, P. (1996). Isolation of microbial antagonists for biocontrol of grey mould disease of strawberries. Biocontrol Sci. Technol. 6, 125-136. doi: 10.1080/09583159650039584

Szczech, M., and Shoda, M. (2004). Biocontrol of rhizoctonia damping-off of tomato by Bacillus subtilis combined with Burkholderia cepacia. J. Phytopathol. 152, 549-556. doi: 10.1111/j.1439-0434.2004.00894.x

Tahsili, J., Sharifi, M., Safaie, N., Esmaeilzadeh-Bahabadi, S., and Behmanesh, M. (2014). Induction of lignans and phenolic compounds in cell culture of Linum album by culture filtrate of Fusarium graminearum. J. Plant Interact. 9, 412-417. doi: 10.1080/17429145.2013.846419

Tariq, M., Ali, Q., Khan, A., Khan, G. A., Rashid, B., Rahi, M. S., et al. (2014). Yield potential study of Capsicum annuum L. under the application of PGPR. Adv. Life Sci. 1, 202-207.

Thacker, U., Parikh, R., Shouche, Y., and Madamwar, D. (2007). Reduction of chromate by cell-free extract of Brucella sp. isolated from $\mathrm{Cr}(\mathrm{VI})$ contaminated sites. Bioresour. Technol. 98, 1541-1547. doi: 10.1016/j.biortech.2006.06.011

Thankamani, V., and Dev, L. (2011). Bacillus isolates VTGP. AD. 30808 Alcaligenes sp., Exiguobacterium sp., B. pumilus and B. fusiformis producing extracellular alkaline proteases, amylases and cellulases-a preliminary report. Res. Biotechnol. 2, 20-30.

Tomioka, K., Takehara, T., Osaki, H., Sekiguchi, H., Nomiyama, K., and Kageyama, K. (2013). Damping-off of soybean caused by Pythium myriotylum in Japan. J. Gen. Plant Pathol. 79, 162-164. doi: 10.1007/s10327-013-0434-x

Torres, M., Llamas, I., Torres, B., Toral, L., Sampedro, I., and Béjar, V. (2020). Growth promotion on horticultural crops and antifungal activity of Bacillus velezensis XT1. Appl. Soil Ecol. 150:103453. doi: 10.1016/j.apsoil.2019.103453

Triveni, S., Prasanna, R., and Saxena, A. K. (2012). Optimization of conditions for in vitro development of Trichoderma viride-based biofilms as potential inoculants. Folia Microbiol. 57, 431-437. doi: 10.1007/s12223-012-0154- 1

Vanitha, S., and Umesha, S. (2011). Pseudomonas fluorescens mediated systemic resistance in tomato is driven through an elevated synthesis of defense enzymes. Biol. Plant. 55, 317-322. doi: 10.1007/s10535-011-0045-3

Velusamy, P., Immanuel, J. E., and Gnanamanickam, S. S. (2013). Rhizosphere bacteria for biocontrol of bacterial blight and growth promotion of rice. Rice Sci. 20, 356-362. doi: 10.1016/s1672-6308(13)60143-2

Verma, S. C., Ladha, J. K., and Tripathi, A. K. (2001). Evaluation of plant growth promoting and colonization ability of endophytic diazotrophs from deep water rice. J. Biotechnol. 91, 127-141. doi: 10.1016/s0168-1656(01)00333-9

Vessey, J. K. (2003). Plant growth promoting rhizobacteria as biofertilizers. Plant Soil 255, 571-586.

Wani, P. A., and Irene, O. I. (2014). Screening of microbes for their metal, antibiotic resistance and plant growth promoting activity. Curr. Res. Bacteriol. 7, 22-31. doi: $10.3923 / \mathrm{crb} .2014 .22 .31$

Warren, Y. A., Citron, D. M., Merriam, C. V., and Goldstein, E. J. (2005). Biochemical differentiation and comparison of Desulfovibrio species and other phenotypically similar genera. J. Clin. Microbiol. 43, 4041-4045. doi: 10.1128/ jcm.43.8.4041-4045.2005

Whetten, R. W., and Sederoff, R. R. (1992). Phenylalanine ammonia-lyase from loblolly pine: purification of the enzyme and isolation of complementary DNA clones. Plant Physiol. 98, 380-386. doi: 10.1104/pp.98.1.380 
Whipps, J. M. (2001). Microbial interactions and biocontrol in the rhizosphere. J. Exp. Bot. 52, 487-511. doi: 10.1093/jxb/52.suppl_1.487

White, T., Bruns, T., Lee, S., and Taylor, J. (1990). "Arnplification and direst sequencing of fungal ribosomal RNA genes forphylognetics," in PCR Protocols: A Guide to Methods and Applications, ed. M. Innis (Cambridge, MA: Academic Press Inc.), 315-322. doi: 10.1016/b978-0-12-372180-8.50042-1

Williams, G., and Asher, M. (1996). Selection of rhizobacteria for the control of Pythium ultimum and Aphanomyces cochlioides on sugar-beet seedlings. Crop Prot. 15, 479-486. doi: 10.1016/0261-2194(96)00014-2

Wojtaszek, P. (1997). Oxidative burst: an early plant response to pathogen infection. Biochem. J. 322, 681-692. doi: 10.1042/bj3220681

Yadav, J., Verma, J. P., and Tiwari, K. N. (2010). Effect of plant growth promoting rhizobacteria on seed germination and plant growth chickpea (Cicer arietinum L.) under in vitro conditions. Biol. Forum 2, 15-18.

Yao, T., Yasmin, S., and Hafeez, F. (2008). Potential role of rhizobacteria isolated from Northwestern China for enhancing wheat and oat yield. J. Agric. Sci. 146, 49-56. doi: 10.1017/s0021859607007356

Yasmin, S., Zaka, A., Imran, A., Zahid, M. A., Yousaf, S., Rasul, G., et al. (2016). Plant growth promotion and suppression of bacterial leaf blight in rice by inoculated bacteria. PLoS One 11:e0160688. doi: 10.1371/journal.pone.0160688
Zahid, M., Abbasi, M. K., Hameed, S., and Rahim, N. (2015). Isolation and identification of indigenous plant growth promoting rhizobacteria from Himalayan region of Kashmir and their effect on improving growth and nutrient contents of maize (Zea mays L.). Front. Microbiol. 6:207.

Zouaoui, M., Essghaier, B., Weslati, M., Smiri, M., Hajlaoui, M. R., and Zouaoui, N. S. (2019). Biological control of clementine branch canker caused by Phytophthora citrophthora. Phytopathol. Mediterranea 58, 547-558.

Conflict of Interest: The authors declare that the research was conducted in the absence of any commercial or financial relationships that could be construed as a potential conflict of interest.

Copyright $\odot 2021$ Hyder, Gondal, Rizvi, Atiq, Haider, Fatima and Inam-ul-Haq. This is an open-access article distributed under the terms of the Creative Commons Attribution License (CC BY). The use, distribution or reproduction in other forums is permitted, provided the original author(s) and the copyright owner(s) are credited and that the original publication in this journal is cited, in accordance with accepted academic practice. No use, distribution or reproduction is permitted which does not comply with these terms. 